\title{
Houses of stories: the whale rider at the American Museum of Natural History
}

${ }^{*}$ Billie Lythberg, ${ }^{* *}$ Jennifer Newell, ${ }^{* * * W a y n e ~ N g a t a ~}$

Abstract

In April 2013, fifteen members of the Māori tribal arts group Toi Hauiti travelled to New York to reconnect with their carved wooden ancestor figure, Paikea, at the American Museum of Natural History (AMNH). They gave educational presentations to school groups, museum staff and members of the public about Paikea and the whare kōrero, or house of stories, which Paikea had adorned as a gable figure. Through a discussion anchored in the importance of taonga (ancestral treasures), this paper describes embodied forms of knowledge used by Paikea's descendants to know him in his absence, and introduce him to diverse audiences. Its foci are: museum education in multicultural contexts; learning by doing through the use of interactive activities; and community outreach and museum education. In addition, it discusses the challenges to protocols and opportunities for learning offered to AMNH staff through this engagement, and examines the impact it had on Toi Hauiti members themselves.

Key words (3-5): museums and source communities; object-centered learning; embodied knowledge; outreach; inreach

Uia mai koia whakahuatia ake - Ask and you will be told

Ko wai te whare nei e? - What is the name of this house?

Ko Te Kani - It is Te Kani

Ko wai te tekoteko kei runga? - And who is the sentinel on top?

Ko Paikea! Ko Paikea! - It is Paikea! It is Paikea!

Whakakau Paikea hi! - Paikea who transformed

Whakakau he tipua hi! - Into an ancient being of the sea

Whakakau he taniwha hi! - Into the great denizen of the deep

Ka ū Paikea ki Ahuahu - And came to shore at Ahuahu

Kei te whitia koe - He is not one and the same as

Ko Kahutiaterangi - Kahutiaterangi

$E$ ai tō ure ki te tamāhine - And he did marry the daughter

A Te Whironui - Of Te Whironui

Nāna i noho Te Rototahe - Who lived at Te Rototahe

Aue, aue, he koruru koe, e koro e-You are now a figurehead, old one

This haka (chant) was composed in 1880 by Mikaere Pēwhairangi of Tokomaru Bay on the East Coast of the North Island of Aotearoa-New Zealand..$^{1}$ It is a synopsis of the Paikea story; a story of sibling rivalry and tragedy in Hawaiki, the Pacific homeland of the Māori. A younger 
brother, Ruatapu, jealous of his father's attention to his older brothers, takes them out in a canoe, capsizes it and proceeds to kill them all. Paikea escapes with the aid of his mothers' ancestors, the whales, and comes to shore at Ahuahu (Mercury Island) in the Coromandel region of Aotearoa-New Zealand. He eventually makes his way eastwards to the Tairāwhiti (East Coast region) and meets and marries Huturangi, the daughter of Te Whironui mentioned in the haka above. They move south to Rototahe and then Whāngārā, where they settle.

From a very young age we were exposed to the stories and performances about Paikea, consciously and unconsciously absorbing a body of knowledge stretching back some 30 generations. Like many young people of the Tairāwhiti we joined in with our old people when they sang or performed the haka, not fully understanding its significance while being caught up in the joy and exhilaration that haka inspires. It is only in later life that one is able to piece the stories together into a coherent whole and appreciate the rich cultural capital contained therein.

This is the story of Paikea, the story of our ancestor, the story of our house, the story of our taonga.

- Wayne Ngata, March 2013

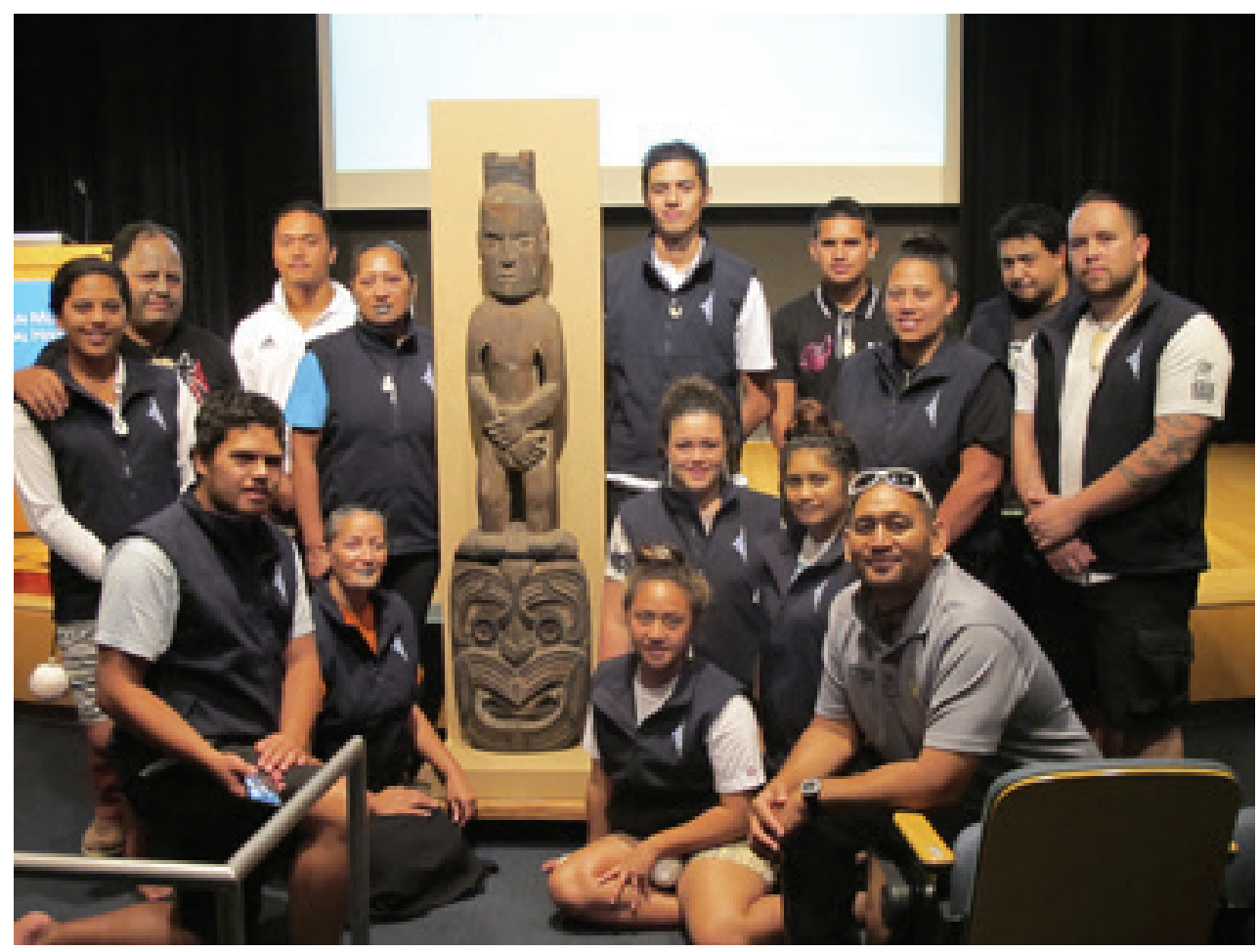

Fig. 1: Toi Hauiti with Paikea, American Museum of Natural History, 16 April 2013. Photo by B. Lythberg.

\section{Introduction}

In April 2013, 15 members of the Māori group Toi Hauiti, made up of students, young leaders and artists from Uawa (Tolaga Bay) on the east cape of New Zealand's North Island, travelled to New York to reconnect with their carved wooden ancestor figure, Paikea, at the American 
Museum of Natural History (AMNH). Toi Hauiti is a working arts committee of Te Aitanga a Hauiti ('the descendants of Hauiti'). Paikea is their enigmatic, whale-riding ancestor, and was the gable figure of their ancestral house, Te Kani a Takirau, 'a house of many stories'. In the early nineteenth century, Te Kani a Takirau was dismantled and parts of it were sold to collectors, but its stories and legacy have remained with its people.

Reconnecting with taonga (ancestral treasures) such as Paikea is one way that younger Te Aitanga a Hauiti people are inducted into their cultural inheritance, and to mātauranga Hauiti (Hauiti knowledge and knowledge systems). 'In te ao Māori [the Māori world], the child is considered a learner from the time of conception, providing the child with the ability to recall the past, connect with the present and to explore the unknown' (Clarkin-Phillips et al. 2012: 12). Though absent in physical form, the stories woven around taonga such as Paikea keep them present and alive for community members. At AMNH, New York's own house of stories, members of Te Aitanga a Hauiti, including elders and their children, chose to share their reconnection with Paikea, and in doing so offered audiences a glimpse of mātauranga Hauiti. Through educational presentations to school groups, museum staff and members of the public, both Toi Hauiti and their audiences gained knowledge. Toi Hauiti employed particularly 'Hauiti' strategies to engage their audiences across generational and cultural divides, including interactive action songs and a reenactment of the generations connecting the youngest Hauiti descendant to Paikea. These techniques prompted audiences to exercise their own creativity and imagination in order to understand the significance of Paikea to Te Aitanga a Hauiti, and glimpse the performative dynamics, roles and functions that taonga have. The educational components of this cross-cultural encounter offered opportunities to move beyond the museum as a 'contact zone' (Clifford 1997: 214) into a zone of exchange - a place for 'humanizing' experiences (Schorch 2013: 70).

Through a discussion anchored in the importance of taonga for Hauiti's descendants, and the ongoing outreach activities of both Te Aitanga a Hauiti and the AMNH, our paper explores the following themes: museum education in multicultural contexts; learning by doing through interactive learning; and community outreach and museum education. It describes embodied forms of knowledge used by Paikea's descendants to know him in his absence, and to introduce him to diverse audiences. In addition, it presents the challenges to protocols and opportunities for learning offered to AMNH staff through this engagement, and examines the impact it had on Toi Hauiti members themselves.

The paper begins by introducing the two houses of stories that converged in New York in April 2013, and their approaches to objects and the types of knowledge and education made possible by them. It then describes the specific educational opportunities available to the AMNH, its audiences, and Toi Hauiti, through Toi Hauiti's reacquaintance with Paikea, their whale rider in New York.

\section{Two houses of stories}

Toi Hauiti comprises artists, schoolteachers, school pupils and their parents, university and government advisors, and other professionals. Its members descend from the eponymous ancestor Hauiti, who lived in Uawa in the sixteenth century. Hauiti's father was a Tohunga whakairo (priestly carver) called Hingangaroa who established an important whare wānanga (house of learning) known as Te Rāwheoro, through which Te Aitanga a Hauiti and other tribal groups received mātauranga or knowledge. Toi Hauiti have been working for more than 30 years to reassemble remnants of Te Rāwheoro's corpus of knowledge - many of them in the form of wooden carvings - acknowledging the capacity of these taonga to enhance and guide their socio-cultural continuity (Ngata et al. 2012).

For three decades Toi Hauiti have worked with museums holding parts of their ancestral house Te Kani a Takirau, of which Paikea was the gable figure. They aim eventually to reassemble this house in virtual form. Te Kani a Takirau is a house of stories: mātauranga Hauiti in concrete form. An example of a carved tribal meeting house of the type known as a whare whakairo, Te Kani a Takirau instantiates ancestral presence and records ancestral stories. Each of its carvings, including Paikea, speaks of journeys made, knowledge gained, conquests achieved, children born, battles fought, lost and won; the history of the descendants of Hauiti, and before 
him, the descendants of Paikea. From the first day of their visit, Toi Hauiti's chairman, Wayne Ngata, referred to this historic meeting house as a house of stories, a whare kōrero. There is no better term to highlight the significance of both the historic house in Uawa, and the museum in New York, and underline the link between these two 'houses'. Though different in many ways, and deeply at odds in important respects, they are united in wanting to cloak objects with the stories that give material things their context and make clear their changing meanings, their active part in the past, and their ongoing significance for the world of the living.

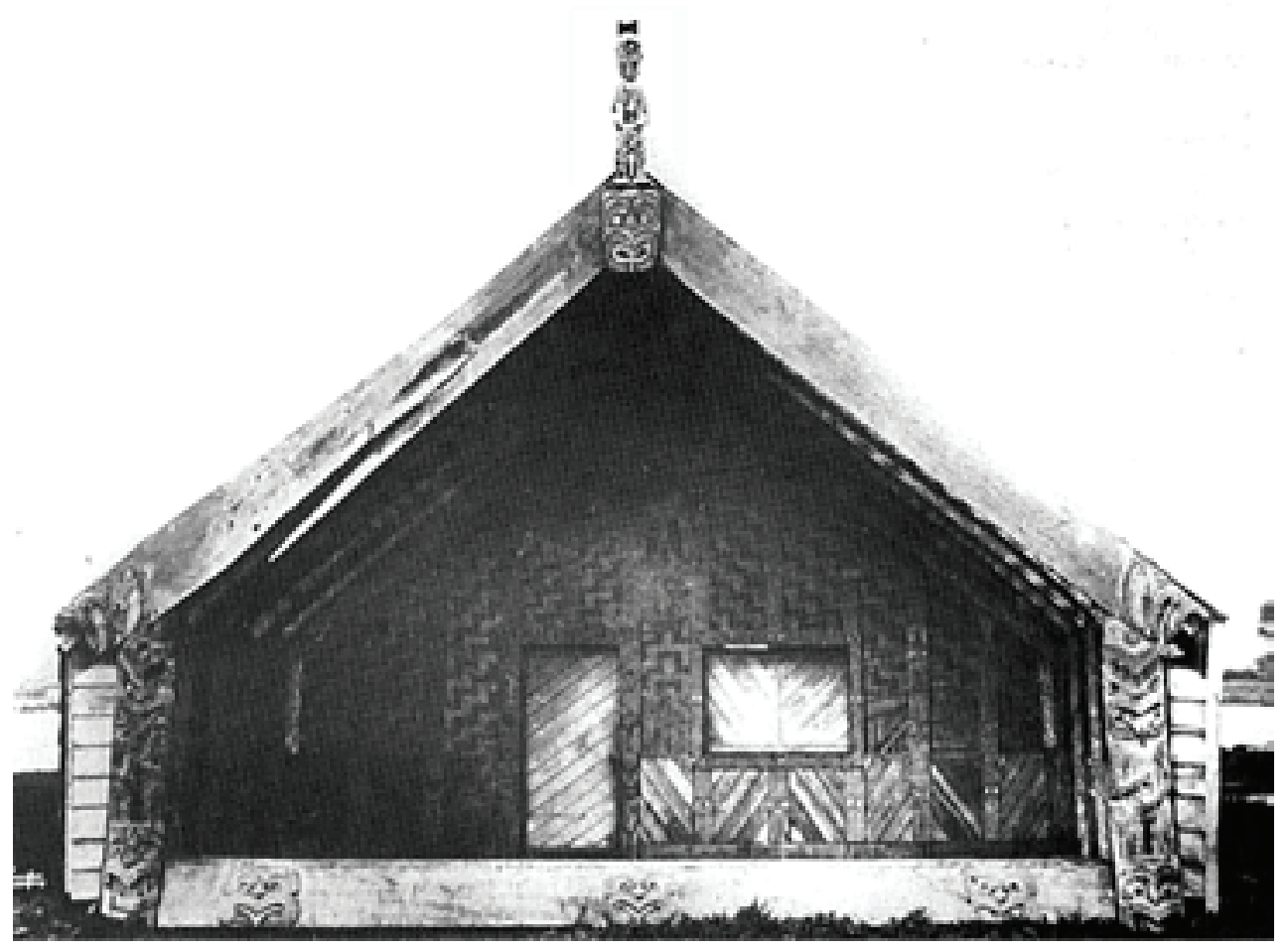

Fig. 2: Paikea, gable figure on ancestral meeting house, Te Kani a Takirau, Uawa, AotearoaNew Zealand. Photo by Augustus Hamilton, 1890s, courtesy of Te Aitanga a Hauiti.

\section{Paikea's legacy}

While escaping the murderous intent of his brother at sea, Paikea summoned his whale ancestors through the incantation of karakia whakakau - a chant to help him survive at sea. This story of Paikea is one of the gems of a Māori oral literature rarely used today. Subsequent to this it has been adapted by Paikea's descendants to suit different occasions; as a pātere or a chant to stir the emotions, as the haka above to dedicate a new house, as a waiata a-ringa an action song derived from the haka, as a novel - The Whale Rider - and as a movie of the same name. Paikea lives on through his descendants and through the various expressions of his legacy, including the Paikea tekoteko (carved figure). The meeting house Paikea once sat atop was named after Te Kani a Takirau (c. 1790-1856), one of the last traditional upoko ariki (paramount chief) of the tribes of the eastern seaboard of the North Island of Aotearoa-New Zealand, and also of course a descendant of Paikea. In order to put this story into perspective the following whakapapa (genealogy) is provided to show the relationship of Paikea to Hauiti and to Te Kani a Takirau; 


Paikea
Rongomaituaho
Te Aomārama
Tātaiarorangi
Te Huapae
Te Rangihopukia
Hinehuhuritai
Manutangirua
Hingangaroa
Hauiti
Hineterā
Tūtekohi
Tamatanui
Hurawaikato
Te Whakahīoterangi
Te Whakapuiorangi
Pōnui
Konohi
Marukauiti
Tānetokorangi
Hinematioro
Ngārangikahiwa
Te Kani a Takirau

Te Kani a Takirau was a prominent chief of the eastern seaboard tribes of the North Island of New Zealand. Numerous senior genealogical lines of these tribes converged firstly on his grandmother Hinematioro, who lived during the time when British explorer Captain James Cook arrived in Uawa in October 1769, and then on him. He lived during a period of tension, turmoil and economic adventure in New Zealand, and was one of the few chiefs asked to be the Māori king. His response to that request was to point out the fact that he was already a king, a title derived from his ancestors; and that his mountain Hikurangi, like him, would remain steadfast in the face of the challenges ahead. He lived most of his life between Uawa (Tolaga Bay), Whāngārā and Tūranga (Gisborne). Although his children died without issue, his legacy was maintained through his adopted son and his wider family and he continues to be acknowledged and revered to this day.

- Wayne Ngata, March 2013

Paikea himself is an enigmatic, whale-riding ancestor to whom Te Aitanga a Hauiti and other tribes of the East Coast are said to sing from the time they are born. Paikea was made famous internationally by Māori novelist Witi Ihimaera in his book, The Whale Rider (1985), and the very successful film of the same name by Niki Caro (2003). Ihimaera was inspired to write the 
book in 1985 while living in an apartment in New York overlooking the Hudson River. 'I heard helicopters whirling around and the ships in the river using all their sirens - a whale had come up the Hudson River and was spouting,' Ihimaera recalls. 'It made me think of my home town, Whangārā and the whale mythology of that area.' ${ }^{2}$ It seems somewhat fitting that a whale should visit New York, home to Paikea, and inspire a retelling of his story.

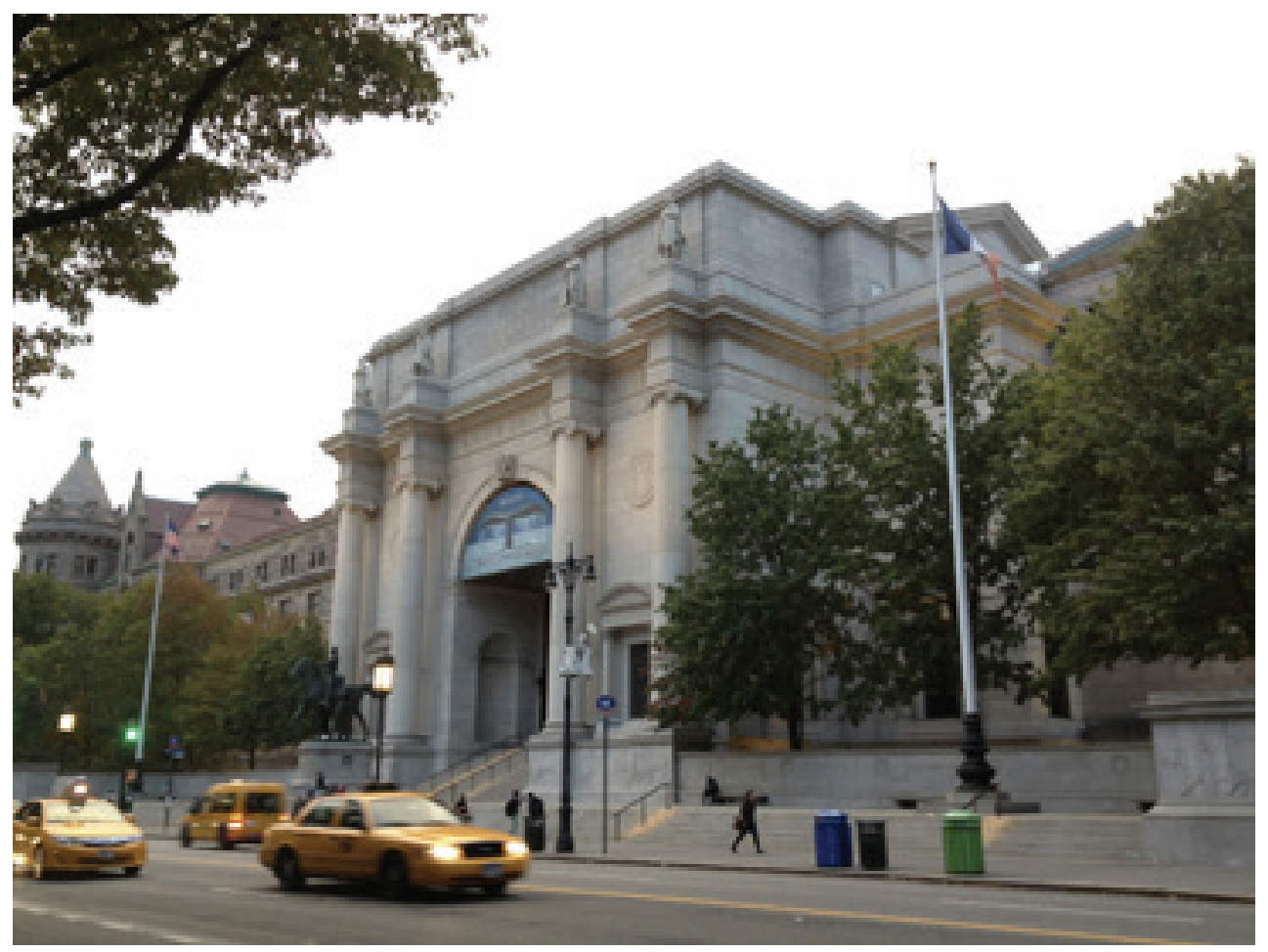

Fig. 3: American Museum of Natural History, courtesy AMNH.

\section{The American Museum of Natural History}

The American Museum of Natural History is, like Te Kani a Takirau, a house of stories. Its mission statement, the motto it inscribes on key-rings and T-shirt tags, is 'to discover, interpret and disseminate knowledge about human cultures, the natural world, and the universe.' Though objects are not mentioned specifically within this statement and many of the museum's science exhibits contain few of them, it is home to approximately 33 million specimens and artefacts, and a library of over 2 million items.

The Museum has a long history of outreach founded on its twin goals of scientific research and education, which began when its doors first opened in 1869. This outreach includes taking museum objects out to meet the public. One of the museum's founders, Alfred Bickmore, travelled around New York State giving lantern slide lectures to teachers. During the 1920s, as Billie Lythberg has written,

a Museum staff member, Alfred Sievers, took specimens, films and lantern slides to New York City schools on a customised Indian motorcycle; and more recently a fleet of mobile museums in the form of converted Winnebagos has performed a similar task (Lythberg 2013: 181).

In 2013 an exhibition about whales came to the AMNH on tour from the Museum of New Zealand Te Papa Tongarewa. ${ }^{3}$ Called Whales: Giants of the Deep, the exhibition presented the 
evolution and biology of whales, a full sperm whale skeleton, and captivating displays about the role of whales in Māori culture. It was highly popular, often reaching maximum audience capacity. ${ }^{4}$ This exhibition coincided with Toi Hauiti's visit to Paikea.

The Pacific collection, where Paikea is housed, numbers some 26,000 items. These objects are from across the great breadth of Oceania, and mostly date from the mid-1800s to mid-1900s, with large portions brought in by America's best-known anthropologist, Margaret Mead. Among these are many 'things' that instantiate ancestral presence and potency for their source communities; to Māori they are known as taonga.

\section{Objects that are ancestors}

Taonga are more than objects. As Māori scholars explain, the term is all encompassing and may include people, places, stories, learnings, and indeed, legacy. As such, when they are part of a genealogical record and process they are referred to as taonga tuku iho (treasure passed down from the ancestors), imbued with the many-layered values that accompany that 'passing down'. It could be argued that taonga tuku iho lost some form of value when they were subject to the foreign forms of trade where the value context changed. Māori continue to ask themselves, 'why did our ancestors sell this taonga, or that house, or that object?' Do we judge their intentions and actions by our standards and values of today? Or do we focus on the original intent and value accorded to the taonga at the time it was created and imbued with a life force in order to carry out its purpose? These questions continue to challenge perceptions of taonga and object. The genealogy, the life force (mauri) and the stories that are attached to taonga are what draw their descendants to engage with them. To touch, to talk with, to cry over, to reconnect with them; these are important facets of cultural behaviour, and in fact all human behaviour. These behaviours make the object a taonga, they bring it back to life, and in doing so, bring life to the descendants of those taonga.

\section{Paikea in Aotearoa}

In the 1890s a schoolteacher, Augustus Hamilton, ${ }^{5}$ took photographs of meeting houses in the Tolaga Bay region, including Fig. 2, above. By the early 1900s, ethnographer W. J. Phillipps ${ }^{6}$ was studying whare of the North Island, and in 1944 published a journal paper on 'Carved Maori Houses in the Eastern Districts of the North Island', some of which were, he said, only known only by their photographs (Phillipps 1944: 104-108).

At some point before 1907, some or all of the whare that Paikea graced left Aotearoa. British settlers, soldiers, traders, clergy, scholars and collectors had long been acquiring and trading the things Māori carvers, weavers, and other specialists were producing. Collectors found these works variously exquisite, intriguing, beautiful, fascinating, and exotic. There was a vogue for installing whole Māori houses in English country gardens (Neich, 2003). The Paikea tekoteko was, at some stage, shipped to England. There it was in the possession of Major General Horatio Robley (1840-1930). Robley had fought in the New Zealand Wars, 1864-66, and had developed an interest in aspects of Māori life, particularly tattooing practices (Robley 1896).

Paikea is still maintained in his home of Aotearoa. In physical form, he has been recreated as a tekoteko on the house Whitireia at Whāngārā, carved in 1936 and featured in the film, Whale Rider. He is kept alive through story, performance, art, text, film, and in life, through and by his descendants. He is frequently recalled in mōteatea, waiata ā-ringa, and haka (chants, action songs and posture dances), and transmitted inter-generationally as part of a normal process of learning and living. He is invoked in oratory when visiting related tribes in other regions of Aotearoa-New Zealand, as his descendants have spread far and wide. This ensures that the living connections and the positive effects of whanaungatanga (familial relationships) are continually reinforced through these references to long dead ancestors. These genealogical ties through whakapapa and song have a particular power to instantiate potent meaning in Tolaga Bay even in the absence of Paikea, the tekoteko to whom they refer. Learning and performing haka and waiata ā-ringa is an incorporating practice, a practice by which memory is stored and recovered (Connerton 1989). 


\section{Paikea at the AMNH}

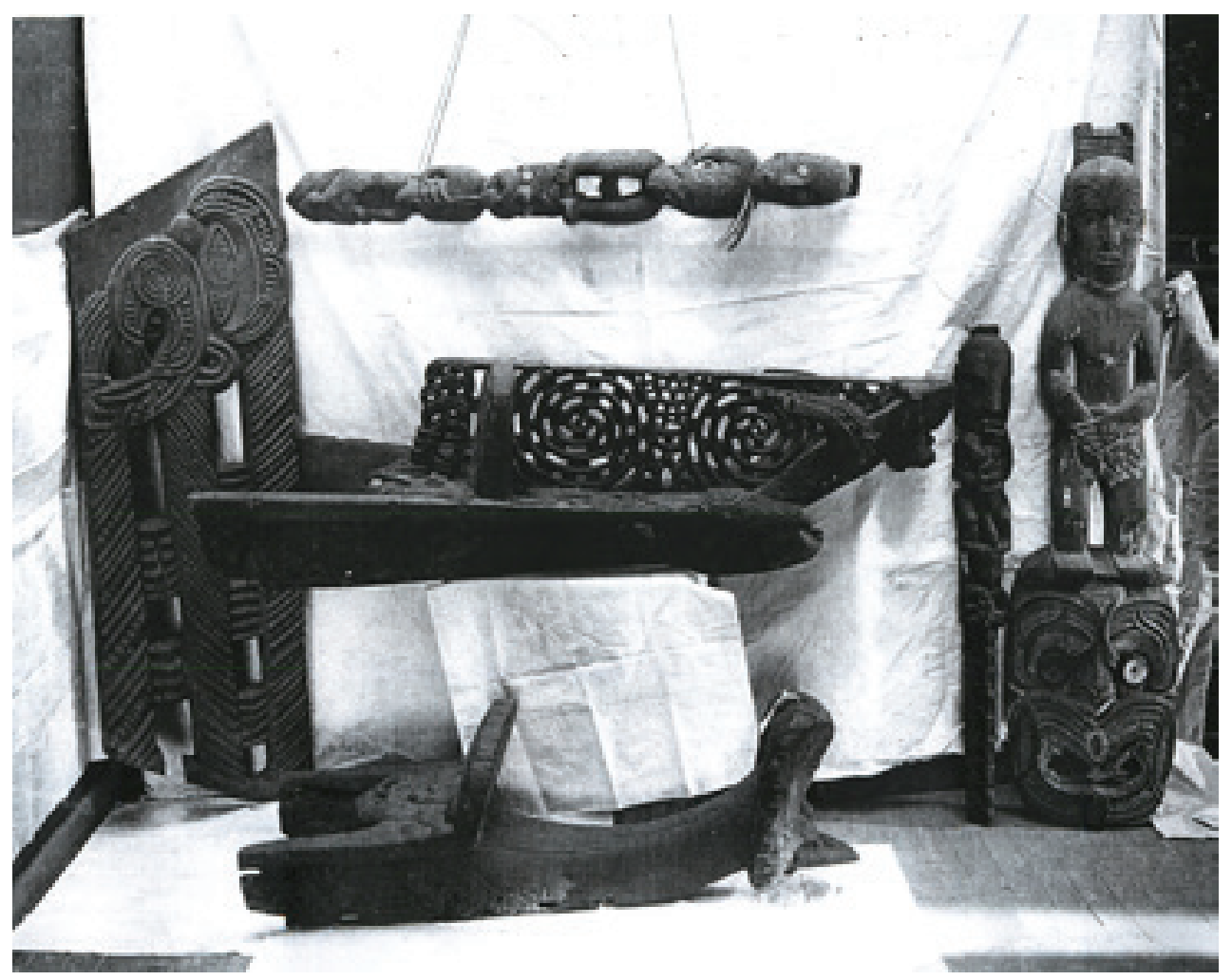

Fig. 4: New acquisitions at the AMNH: Major-General Robley purchase, 1908. Photo by T. Lunt, courtesy of AMNH.

In 1908 the AMNH accessioned several Māori carvings from Robley's collection: two tekoteko, a piece of gable board, and a canoe prow. ${ }^{7}$ Museum photographer Thomas Lunt took a photo of the Robley acquisition on its arrival (Fig. 4). In the photograph, the Paikea tekoteko from Tolaga Bay, on the far right, has an auction-house label on its leg: 'Lot 110'. Paikea can be seen with more white paint than is currently on the surface, and a paua shell inlay is still extant on one eye of the koruru face on which he stands. Having arrived in New York, the house of Te Kani a Takirau became physically part of the house of the AMNH, and both became conceptually entwined. A rare early photographic view of the South Seas Island Hall in 1911 shows Paikea on the wall, facing a life-sized sculpture of a Māori warrior, brandishing a mere on top a 3-ton piece of pounamu (Fig. 5). The monumental piece of jade was a gift from J. P. Morgan, and the Museum had wanted to dramatically adorn it with a Māori figure for the new hall, which opened on the $4^{\text {th }}$ floor on 25 January 1910 . When staff member H. E. Crampton heard that a troupe of Māori performers were going to be in New York for a season at the Hippodrome, he arranged for the group to be hosted at the museum several times during their stay, October 1909 to April 1910. Sigurd Neandross, Museum sculptor, modelled the warrior from 'direct studies' of a young man in the dance troupe, Hautuoterangi. ${ }^{8}$

During their visits to the Museum, Thomas Lunt took group photographs of the group, and Hautuoterangi, posed for the sculptural portrait that 'danced defiantly at the entrance of the South Sea Island Hall'. ${ }^{9}$ There is no mention of the Māori troupe having met Paikea during their visits. Since then, exhibitions and halls have come and gone. Paikea appears to have 


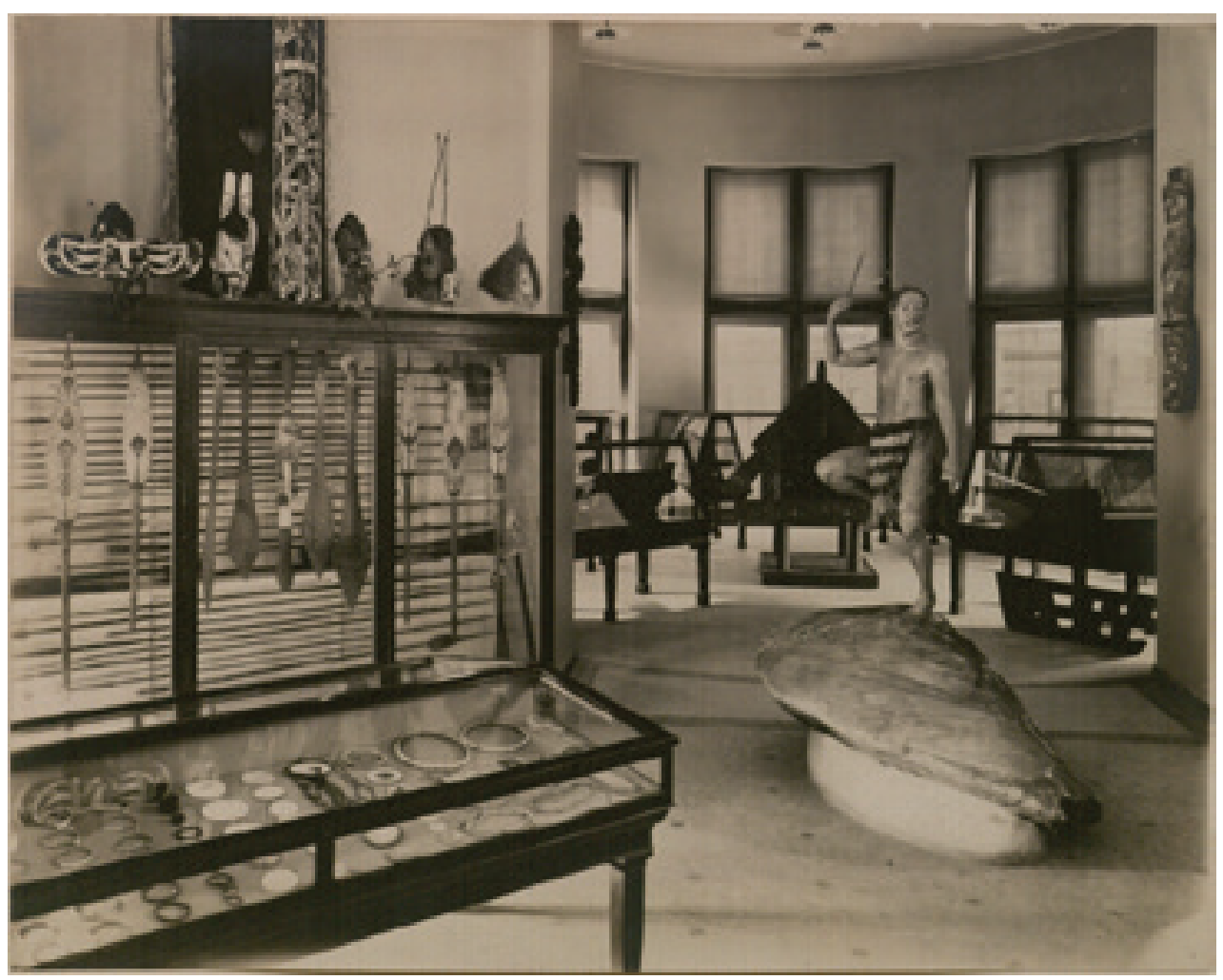

Fig. 5: South Seas Island Hall in 1911, courtesy AMNH.

disappeared from public view when the South Seas Island Hall was dismantled in 1927 to make way for Margaret Mead's overhaul of the display. Mead's new South Sea Natives Hall finally opened in 1939. The current Hall of Pacific Peoples, also curated by Mead, which opened in 1971 , does not seem to have ever included Paikea among its many objects. However, Mead's memos leading towards its design specify the removal of the 'Māori warrior', indicating that the sculpture of Hautuoterangi - unlike Paikea - may have survived the overhaul of the South Seas Island Hall to feature in the South Sea Natives Hall (Wagelie 2007: 147-148).

Though other Māori have followed in the footsteps of Hautuoterangi and his people on visits to the AMNH with personal and professional agendas, it was not until 2013 that Paikea was once again kanohi-ki-te-kanohi 'face-to-face' with his descendants. However, since he left the shores of Aotearoa-New Zealand in the late 1800s, Paikea the tekoteko has been remembered, and for many years his descendants have known of his presence in New York. Since 2005 they have been able to engage with him online through the AMNH anthropology database (Lythberg 2013). At every stage of its history, AMNH has utilized the technology of the day to engage with as diverse an audience as possible. The anthropology database includes illustrated records for more than 200,000 objects from the Americas, Africa, Europe, Asia and the Pacific Islands, including current catalogue information and scans of their manuscript catalogue entries. ${ }^{10}$ The database spans outreach, in-reach and online strategies, allowing people to locate museum objects online and make appointments to visit them in person. Paikea is here: a 'wooden image' made from 'wood/pigment' from the locale 'Tolaga Bay' [Uawa]. ${ }^{11}$ The manuscript catalogue entry records entry number 615, a "Teko Teko" wooden image from a Council House in Tologo Bay, New Zealand' [Tolaga Bay/Uawa], purchased from Major General Robley, and accessioned in 1908. These scant and wholly pragmatic details cloaked Paikea in the absence of his kin, while his kin kept his memory and the stories of his achievements alive. 


\section{Toi Hauiti's preparations}

The Toi Hauiti group that travelled to New York were part of a long standing project, initiated in 2003 with an art exhibition entitled Te Pou o Te Kani (The Legacy of Te Kani) held in Tolaga Bay, and continued by numerous events since, to reconnect through cultural exchange and digital technology with taonga and artefacts from the Uawa region now housed in institutions around the world. In recent years Te Aitanga a Hauiti have worked with the research institute Ngā Pae o te Māramatanga, and tertiary institutions Eastern Institute of Technology, Auckland University and Cambridge University in the UK, on a project named Te Ataakura, to build a digital database of artefacts from the area as part of a drive to revisit and reinforce the cultural capital of Te Aitanga a Hauiti (Ngata et al. 2012, Lythberg et al. forthcoming).

In terms of the Paikea tekoteko, one of the projects that Te Aitanga a Hauiti is proposing is to rebuild the house Te Kani a Takirau in digital form, using the data, images, relationships and expertise built up over the past ten years as a first step towards rebuilding the house itself. Hauiti visited other pieces of the house in Florence and London in 2012. ${ }^{12}$ In 2013 the 'Artefacts of Encounter' research project (based at the Museum of Archaeology and Anthropology, Cambridge $)^{13}$ and the University of British Columbia invited Toi Hauiti to participate in an international workshop and present on their Digital Taonga Repatriation project. ${ }^{14}$ This offered the chance to spend time with First Nations people on Vancouver Island, and an opportunity - on the way home to Aotearoa-New Zealand - to visit Paikea in New York while the Whales exhibition was on display.

While Toi Hauiti had been working towards their particular reacquaintance with Paikea for the previous ten years, it had been more than 105 years since Paikea was last seen by his descendants. It was a hugely significant step. Toi Hauiti therefore committed to a date to arrive, applied to the museum with a plan for their visit, conducted significant fundraising within their small community, and assembled a robust group to travel to New York.

\section{Preparations by the AMNH curatorial and collections management teams}

At AMNH, the return of Paikea's whānau (extended family) began in a curatorial office, when Pacific Curator Jenny Newell received an email from Aotearoa-New Zealand, suggesting a visit from members of Toi Hauiti and their research colleague, Billie Lythberg. Calling up the collection database, Newell found Paikea's record, with a photo of a handsome carved figure with an arresting gaze. Newell recalls noticing this figure not long after she arrived at the museum, in the storeroom, on a shelf, staring - 'it really looked as if it was staring' - at the shelf above, inches away from its face. Agreeing to a meeting with Toi Hauiti was easy (and made more straightforward by Newell's having met and worked with them and Lythberg at the Te Ataakura and Artefacts of Encounter projects' symposium Digital Subjects, Cultural Objects in Auckland, 2010). ${ }^{15}$ The group then made a more complicated request: to come in to not only meet Paikea but to introduce him to the people in the Museum and to New Yorkers, the people who are his neighbours. Toi Hauiti were keen to set up a space where they could do a presentation for staff and the public, and to have Paikea on the stage with them. They would bring a film crew with them, a small group of their own tribal members. As she considered the challenges this would present for conservators, mount makers, the education team, and collection staff, Newell was unsure whether there was any hope of making this happen in time.

But the museum cogs turned. Toi Hauiti and the Education Department at the Museum had a series of discussions on email and Skype. Together, they designed a program of performances for school groups, families and staff that would run for a session, or two sessions back to back, of about an hour each, every afternoon for a week. The audience was to be primarily groups of children and their families enrolled in an after-school science education series, but the audience reach would later be expanded to include any Museum visitors, by announcing the performances on the public address system. Lythberg, Newell and Ngata kept in close contact, and the insights and guidance Lythberg provided to the curatorial team helped them to work with Toi Hauiti more effectively, from a well-informed foundation.

In order to allow Paikea to stand upright, as he had at the apex of the meeting house, a Museum carpenter created a custom-designed wheeled mount. Some existing brackets on 
Paikea's back, from an earlier period of display, were used as attachment points. The paint on the mount dried and completed a period of off-gassing with no time to spare: Paikea was lifted on to his new upright plinth the morning Toi Hauiti arrived.

\section{The first meeting with Paikea}

Toi Hauiti came to AMNH on a fine autumnal day, and assembled in the small Linder Theater on the Museum's ground floor. They ran through their dances, the teenagers joked around, the adults talked amiably, and their film team went through checks and short runs of videoing the activities. Then, as the designated time arrived, the group drew together, Ngata addressed them, and they faced the door where Paikea was to be brought in. This would be a pivotal moment for the success of the visit: the moment when ownership would be at issue and responsibility for Paikea's physical wellbeing temporarily returned to members of his kin.

Paul Beelitz (Director of Collections and Archives) and two collections staff wheeled Paikea

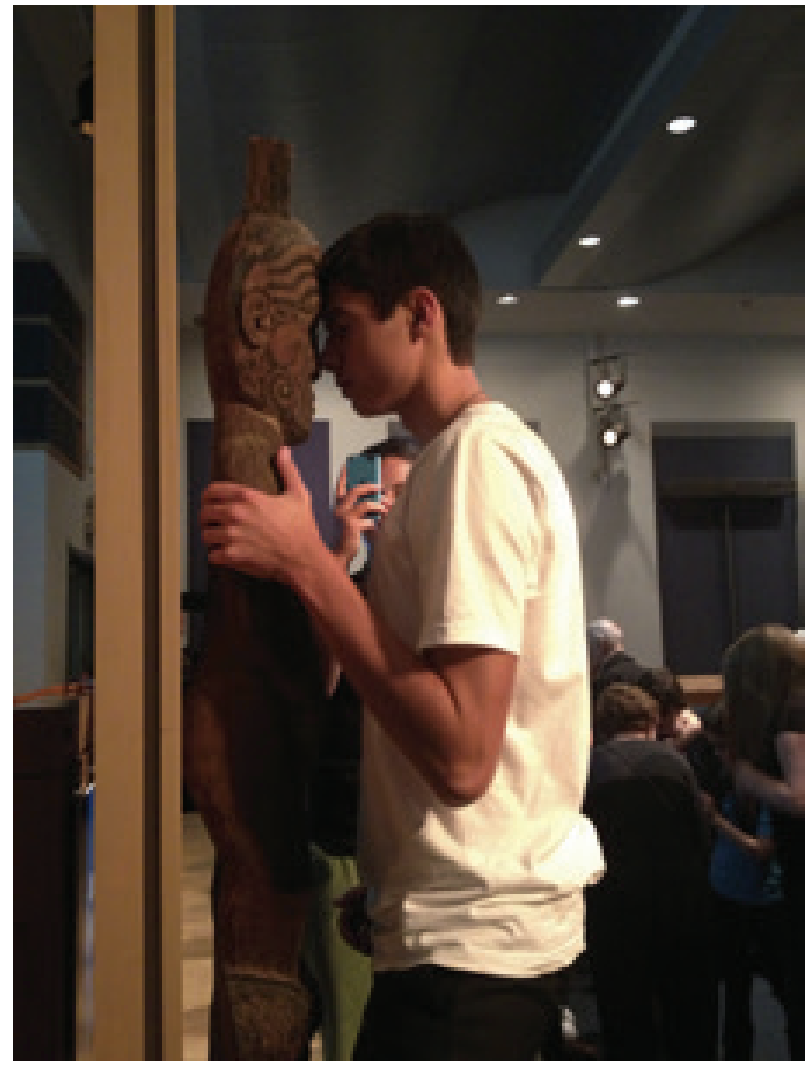

Fig. 6: Owen Wharekaponga Rayner shares a hongi with Paikea. Photo by J. Newell. in, then fell back. Two of the Toi Hauiti men stepped forwards to bring Paikea towards the group, and Paikea's haka filled the theatre. 'Uia mai koia, whakahuatia ake; Ko wai te whare nei e? Ko Te Kani. Ko wai te tekoteko kei runga? Ko Paikea, Ko Paikea! - Ask and you will be told; What is the name of this house? It is Te Kani. And who is the sentinel on top? It is Paikea, It is Paikea!' Te Aitanga a Hauiti people are said to be born doing this haka; for those Hauiti in New York that day, this was the first time they had done so in the presence of Paikea, the tekoteko they address every time they perform this important celebratory chant, or sing it as a waiata â-ringa with poi (swinging balls/pompoms) and other actions. One of the teenagers would later comment, 'It was like my whole life finally made sense'. ${ }^{16}$

Following the haka, Ngata addressed Paikea in a formal way, introducing him to his kin and speaking of the distances that had been between them. The separation of time and space was collapsed when hands were laid on Paikea; some Toi Hauiti members gently caressing his face, others placing their nose to his in the greeting known as hongi (Fig. 6). Throughout, the AMNH staff placed no explicit constraints on if or how Paikea was to be handled. The reunion was a potent experience and $\mathrm{AMNH}$ staff did not wish to intrude. Afterwards, Ngata addressed the museum staff, thanking them and explaining what it meant for the group to have been reunited with Paikea. He said,

Our people have not seen this representation of Paikea since the time of our greatgrandparents in the late nineteenth century. We remember them, their stories, their debates, discussions and performances for and about him, and we acknowledge them, for they are with us today paying homage to our ancestor Paikea. 
Throughout, contact was maintained with Paikea through the gentle touching of kin keen to know him better, learn how he was made, and get closer to their ancestor. The tekoteko Paikea was for that moment - and the week that followed - once again an embodiment of Paikea, the ancestor, Paikea the legacy, and all the descendants of Paikea to the present day. He represented 'te hunga mate', the deceased, and so it was important that they were acknowledged as Māori people do when they meet each other. They do not see just the living person, but they see all their ancestors gone before them and therefore greet them accordingly, through speech, tears, and touch. Making the most of their limited time at the museum to do all of these things was critically important, because each of the Toi Hauiti members there was representative of others at home. They were, through whatever action big or small, hoping to carry out these functions for all of those who were not there. Ideally they would have liked to sleep with him at the museum, as they would have at marae (tribal communal meeting places) at home, and talked and sung with and about him through the night. Paikea, for all intents and purposes, was made human again and kept 'warm' through the duration of the visit. To leave him each day was particularly heart wrenching and had a profound effect, particularly on the younger Toi Hauiti members.

\section{The power of touch: negotiating boundaries and learning about affect}

In-reach has been an active part of the AMNH for more than a century, including the hosting of groups of people for educational or other purposes, including members of source communities. While some groups were hosted sporadically early on, it has been a more regular occurrence over the past few decades, particularly since the NAGPRA legislation of $1990^{17}$ has meant close liaison with Native American and Hawaiian communities about the return of ancestral remains and funerary goods. The anthropology collection at the AMNH is an important site for a set of reconnections by descendant communities who have their own set of missions: reclaiming the ability to see, touch and speak to objects of significance, and to have the power to mediate the stories that are told about these things, and about themselves. Perhaps the most powerful of these experiences, and the most difficult to negotiate with museum curators and collection managers, is touch. But touch was a vital part of the museum experience for museum-goers of the 1700 s and 1800 s, who, according to Classen;

must have felt a thrill at holding in their hands what long-ago and far-away people had held in their hands... The seeming ability of touch to annihilate time and space give it a particularly vital role in the museum where so many of the exhibits were from long ago and far away. Touch helped bring the museum to life (Classen 2007: 903).

In the environs of the twenty-first century museum, where things are handled precisely and carefully, usually by gloved hands and as infrequently as possible, the desire of source communities to caress, stroke, kiss, and cry over artefacts can be difficult to accommodate. Quite aside from the challenges it presents to conservation, touching denotes a certain type of familiarity that might be construed as ownership (Chartejee et al. 2009: 167). At the AMNH, once Wayne Ngata had spoken his warm words of greeting to Paikea, while caressing his shoulder, he defused tensions and caused all assembled in the room to burst out laughing when he turned, grinned and said 'Right, who has a really big bag?'

Newell and Beelitz had not discussed in advance of the visit what sort of hands-on access they might expect, but they - and Lythberg - had experience of source communities reacquainting themselves with ancestral treasures. Museum staff have a duty of care for the object, now and into the future, a set of responsibilities and perceptions that are hard to sidestep. But this was a special case, the situation calling for a particular approach. The flaking colours on Paikea's surface are not particularly secure, but while Newell and Beelitz were concerned that touching this surface might have worn away a little of that material patina, they also knew that being in a museum does not guarantee objects a perfect stasis - there has been slow degradation, fading and other slow changes to the figure during its time in the museum. With Toi Hauiti's laying on of hands, Paikea's story received a new chapter, one that would be told in Uawa and throughout the world. The deep importance of re-establishing an intimate connection with a lost family member was clear. While not necessarily expressed, 
there was some feeling that permitting Toi Hauiti this reconnection with past, present and future significance had a higher claim than an adherence to a concept of preservation that is standard in the Western museum tradition.

'Objects' like Paikea are touched not only to reconnect with them, but to access information they embody. Explaining how museum objects have been used as a rehabilitation device in hospital environs, Charterjee and colleagues describe patients encountering truths 'only ascertainable through their fingers', touching objects 'in order to determine texture, weight, temperature and how the object related spatially to their bodies' (Charterjee et al. 2009: 165). For Toi Hauiti, touching Paikea added knowledge to existing mātauranga Hauiti; for the artists present, it revealed knowledge unobtainable in any other way. Just as Paikea the man, the whale and the tekoteko are inseparable, so too the mātauranga he encompasses is inseparable from bodily ways of knowing him. From the haka, poi dances and action songs performed for him, to touching him when face to face; all are embodied forms of knowledge and knowing. In terms of knowledge retention and depth of understanding, these go beyond the knowledge obtained from written words and digital surrogates, such as those accessed through online databases. Hammond and Simpson's exploration of 'the physicality of object engagement' in the use of museum objects at Macquarie University lead them to suggest that there are 'distinct pedagogic advantages in direct object engagement in comparison with digital surrogates' (Hammond and Simpson 2012: 78), a suggestion that underpins the importance of face-to-face and skin-to-skin contact between Paikea and Toi Hauiti.

Just as Fiona Candlin has identified the distinctive ways that visually impaired people touch objects in order to know about them (Candlin 2007: 94), at AMNH Toi Hauiti brought awareness to the instructive touch employed by source communities and drew a distinction between this and 'mishandling'. Though initially challenging to collections management staff at $\mathrm{AMNH}$, the familial care with which Paikea was affectionately and respectfully handled, lifted on and off stage every day, and rolled back to storage every evening, quietened anxiety about this contact.

Laura Peers has recently written about the long-term project of sharing ancestral quillwork shirts in the Pitt Rivers Museum (Oxford) with a Blackfoot community in Montana (Peers 2013). Peers writes of the deep scars remaining in the community from the history they have weathered of colonial violence, dispossession from land, and loss of cultural patrimony. By looking at, touching, and talking about their ancestral shirts, and through activating them in a ceremony of renewal, Blackfoot people, young and old, have reclaimed potent ways to create new social relationships with each other. They have also, through the shirts themselves, reactivated their relationships with the ancestors who created them. These relationships have provided learning opportunities and healing, and - like Toi Hauiti's visit to Paikea at AMNH - laid the positive theoretical and logistical groundwork for further such reconnections to be made.

\section{The presentations}

The privacy and intimacy of Toi Hauiti's reunion with their ancestor that autumn morning was interrupted when the imminent arrival of a school group was announced, and arrangements were made to lift Paikea into place on stage and prepare to introduce him to New York. Powerpoint presentations were checked and readied, poi tucked into belts for use later on, and mere (hand clubs) grasped firmly in the hands of the men who would lead the haka for this and every group that came through the theatre doors.

The first audience to file into the AMNH theatre had no idea that just half an hour beforehand, the group now poised on stage had offered greetings to their ancestor, the carving standing on stage with them. They saw a man standing behind a podium to stage right with a group of men, women and teenagers onstage with him: women at the front, men at the back. They were probably intrigued by Ngata's full-face Māori tattoo, known as moko, and by his wife's and female cousin's chin tattoo, or moko kauae. Later, they would ask about these, but not before they had been regaled with the story of Paikea, enacted his whakapapa or line of descent, learned some of the actions and lines of Paikea's haka, and watched poi twirl and eyes widen in pūkana (a challenging glare). 


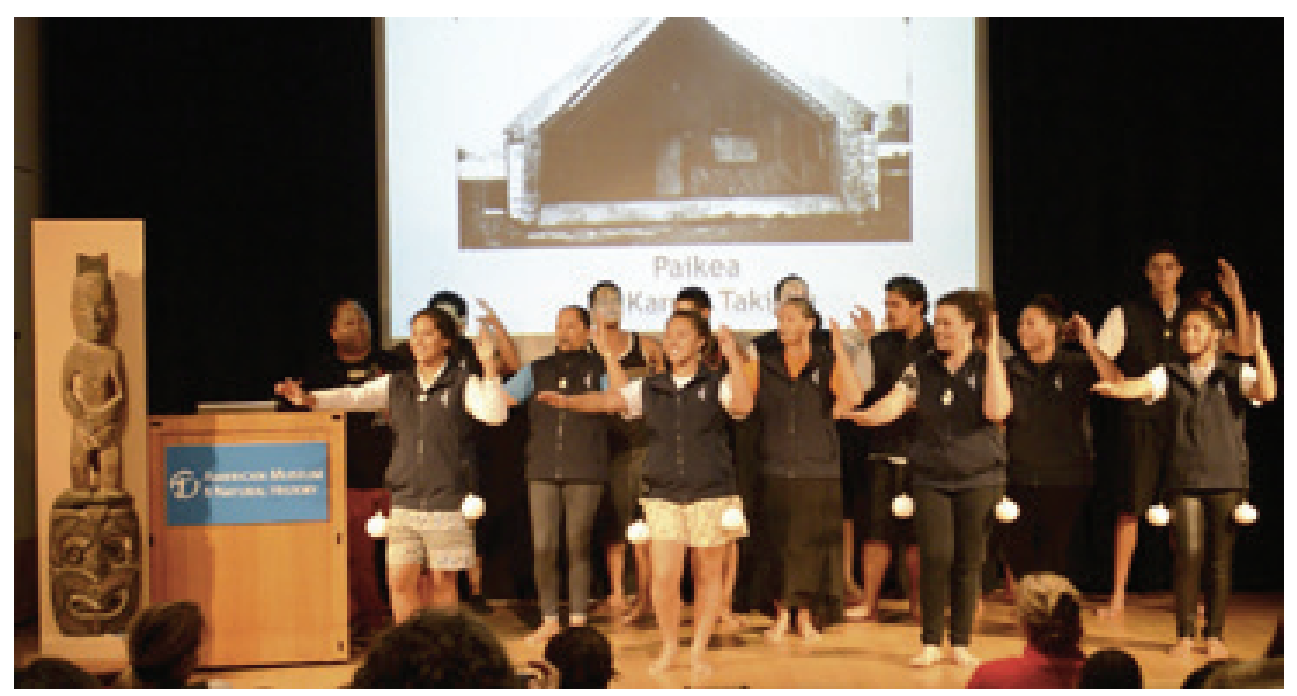

Fig. 7: Toi Hauiti perform with Paikea. 16 April 2013. Photo courtesy of AMNH.

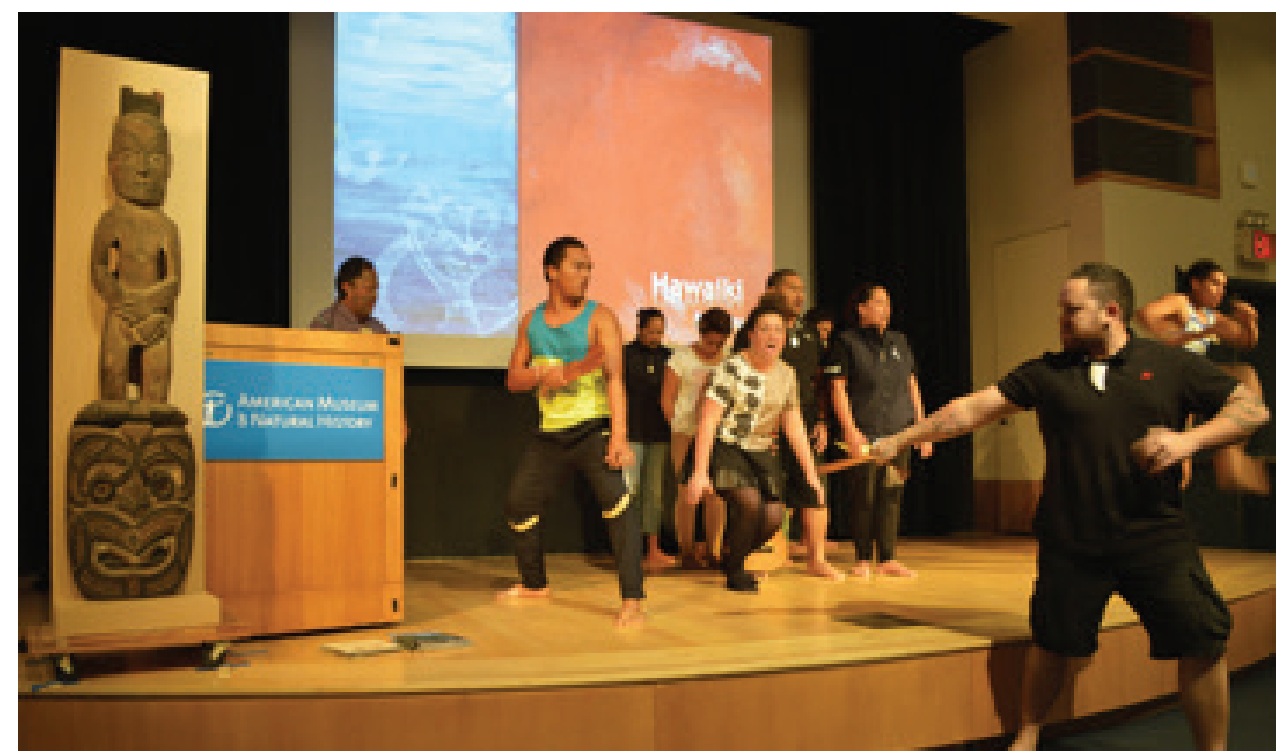

Fig. 8: Haka for Paikea. 16 April 2013. Photo by J. Newell.

The ability to reconnect with Paikea and then almost immediately share stories about him, sing his songs, perform his haka and demonstrate his whakapapa, does not indicate that his reacquaintance was quickly made. Rather, it indicates an understanding that through introducing Paikea to others, through singing, performing, and acknowledging whakapapa links repeatedly for a week, his reacquaintance was being performed. In turn, this underscores why Toi Hauiti made the request to introduce Paikea to New York: because in doing so they would be reintroduced to him.

Every audience received the same information about Paikea, regardless of their age and composition, but every group received a unique experience. Though Ngata remained at the 


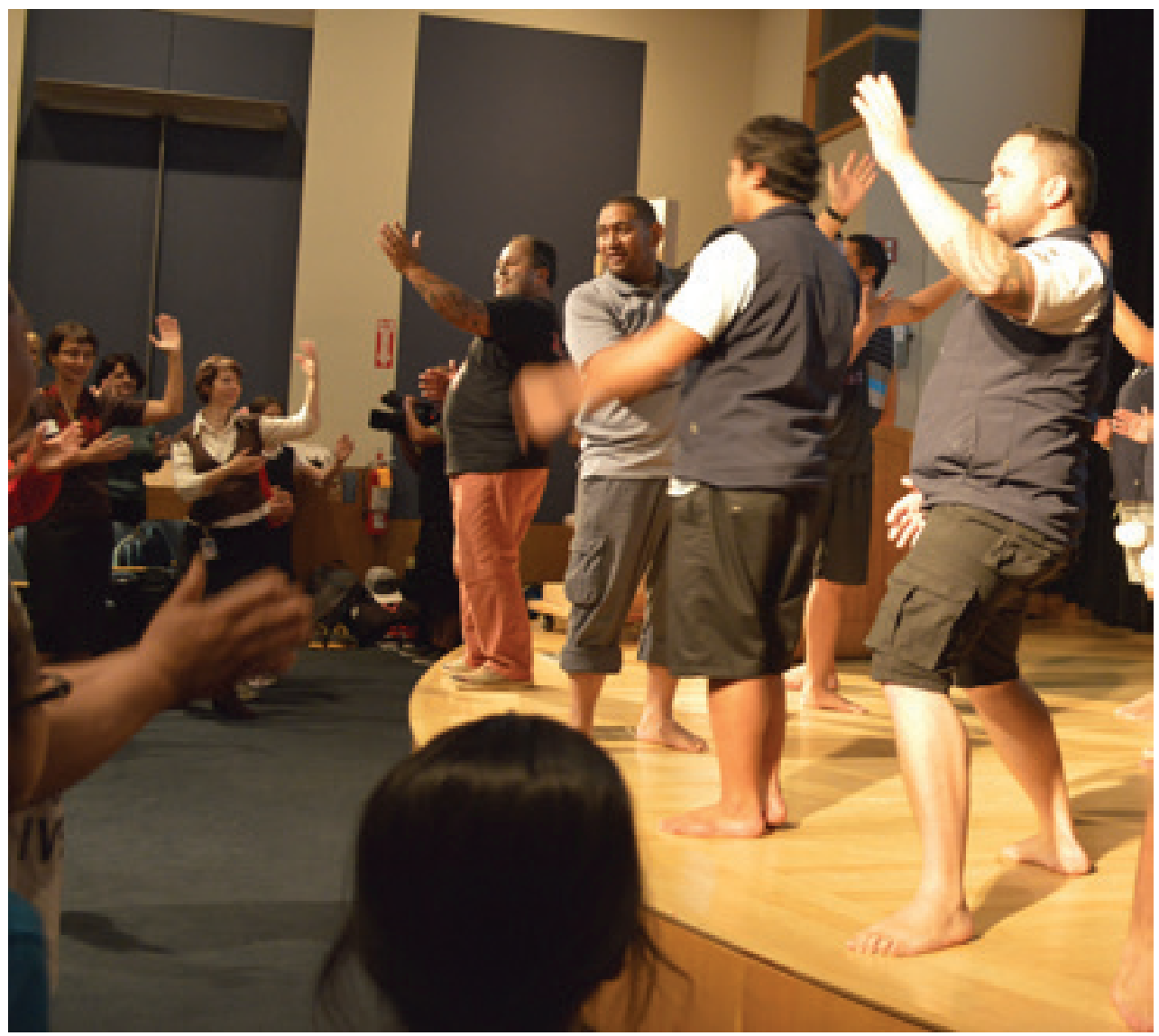

Fig 9: The audience learns to dance a haka. 16 April 2013. Photo by S. Pykare, AMNH.

helm, the people explaining each section of the presentation changed from session to session. The fluidity of Toi Hauiti's presentations was made possible by extensive preparation, some of it deliberate, but most derived from a lifetime of exposure to the numerous expressions of Paikea and Te Kani a Takirau. While Te Aitanga a Hauiti - like other tribes of the Tairāwhiti - are said to be born doing the haka to Paikea, in fact it is one of several haka and waiata ā-ringa that children grow up learning through participating in and watching various cultural activities that take place in communities in Uawa (Tolaga Bay).

The purpose of the presentations about Paikea was to build relationships; reconnecting first with Paikea, Te Kani a Takirau and other ancestors by bringing them back to life through story-telling. Secondly, it was to build relationships with the people of the Museum and of New York who currently act as guardians of Paikea. By doing so, Toi Hauiti found some comfort in bridging physical and cultural gaps between place and people.

\section{Photographs}

Just as Paikea was welcomed by Toi Hauiti through a thundering rendition of his haka, so too were audiences welcomed as Toi Hauiti sang about their ancestor while they filed into the theater. When the audiences had taken their seats, each presentation began with an introduction from Ngata, using a Powerpoint slideshow to immediately collapse the time and space between Paikea in Uawa and Paikea in New York. Paikea was shown in situ, at the apex of the meeting house, in old photographs, the tones and imperfections of which underpinned 
their temporal distance, yet allowed his presence in Uawa to be substantiated. He was clearly visible atop the gable of the whare. Likewise Te Kani a Takirau the man was shown in a handcoloured photograph that immediately shattered any ideas of his being in any way mythical. The photographs used have been significant media for instantiating Paikea and Te Kani a Takirau's presence in Uawa.

Photographs, to Māori, are taonga (Brown 2008). 'No distinction is made between sacred objects, and the like, and copies (including photographs) of them. All are equally powerful, sacred, or otherwise instilled with vital values and thus require appropriate care and protection' (Brown and Nicolas 2012: 314). This is in direct contrast to the usual treatment within museum contexts where they are tools that offer the 'look of the past' (Porter 1989: 24) in order to 'authenticate other classes of objects, to give "period"' (Edwards and Mead 2013: 21).

They are seldom represented as integral to the knowledge-making practices of museums, and are often marginalized and undervalued as significant players in museum practice. As a result, they are denied their own historicity and their own social biography as dynamic forces in the making of museum narratives (Edwards and Mead 2013: 22).

By bringing their photographs of Paikea and Te Kani a Takirau back to AMNH, Toi Hauiti not only invited their audiences to verify their presence in Uawa, but also presented what for Toi Hauiti are integral parts of knowledge-making and knowledge-transferal within their community.

\section{Haka and action songs as incorporating practices}

During every session, each group was asked to stand, and was taught the opening lines of Paikea's haka and its actions: gestures up to Paikea, the tekoteko; the trembling hands known as wiri (being performed in Fig. 7); slapping hands on thighs; co-ordinated foot movements, keeping time with the song.

When the groups were taught parts of the Paikea haka they were learning not only an 'action song' but what Connerton has called an incorporating practice, a way of incorporating some of what they learned for better memory storage and later recovery (Connerton 1989). Children in particular learn songs and accompanying actions very quickly, and the school audiences were able to approximate the haka convincingly. Chanting, singing, learning-by-rote: the methods used in Uawa to teach the fundamentals of ancestral knowledge transferred easily to New York's school children. Tellingly, the hand movement most difficult to grasp, and the one that required the most explanation, is wiri, which to Māori indicates the interface between the mind and the body. This deep ancestral knowledge is acknowledged by embodiment theorists, who argue that 'knowledge is not detached from the body and concepts of physical intelligence and bodily learning have become accepted among learning theory' (Charterjee et al. 2009: 169). The learning of action songs, which the mind and body work together to recall, enacted the potential for personal reminiscence (nostalgia and meaning making) as opposed to what might be considered detached or impersonal education (Charterjee et al. 2009: 171).

\section{How whakapapa was made visible}

Incorporating practices were used again to convey the descent line from Paikea, which can be named through to all the members of Toi Hauiti who were onstage. At AMNH, Toi Hauiti members facilitated the recital of an abridged whakapapa by each of its audiences, symbolically representing descent by positioning people in a line in the auditorium, each of them representing an ancestor.

Ngata asked for volunteers, each of whom was partnered with a Toi Hauiti school student who quickly taught the name of the ancestor they would represent. They then called out their names, interspersed with Ngata's prompting 'who had...': Paikea who had Rongomaituaho who had Te Aomārama; right the way down to Te Kani a Takirau, after whom the meeting-house with Paikea at its apex was named. 


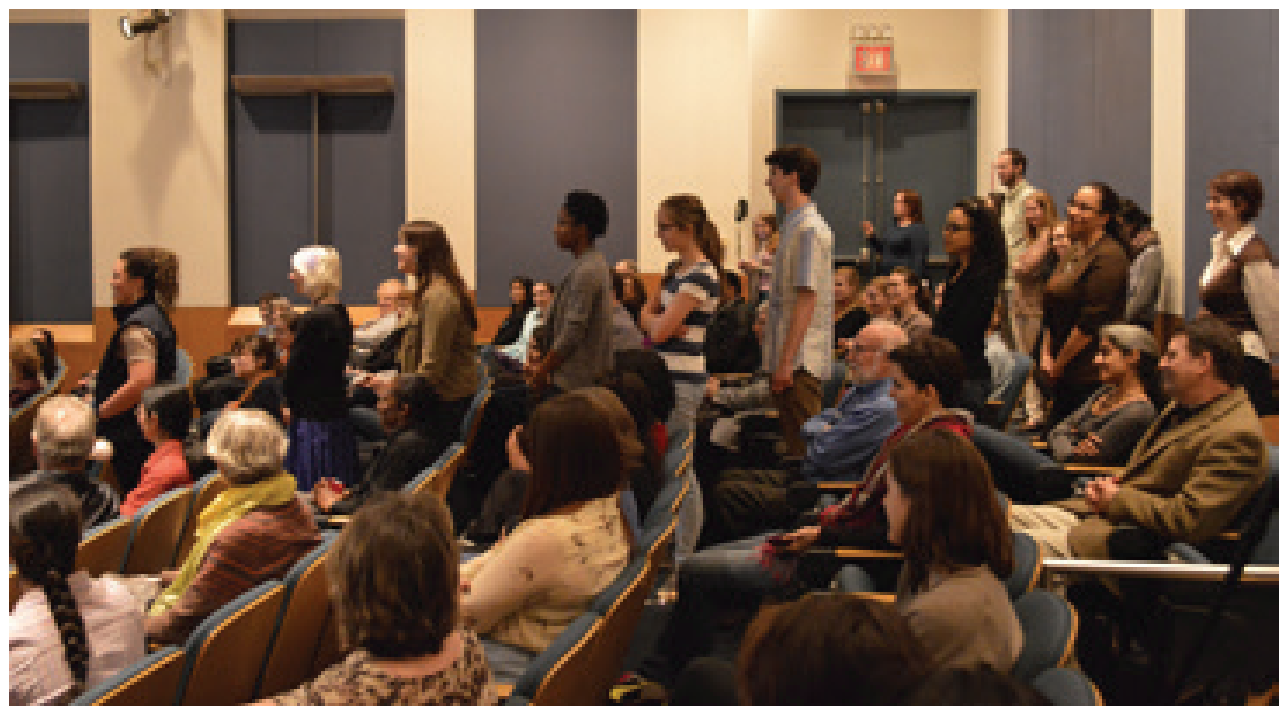

Fig. 10. Whakapapa line-up: education session with Toi Hauiti. 16 April 2013. Photo by S. Pykare, AMNH.

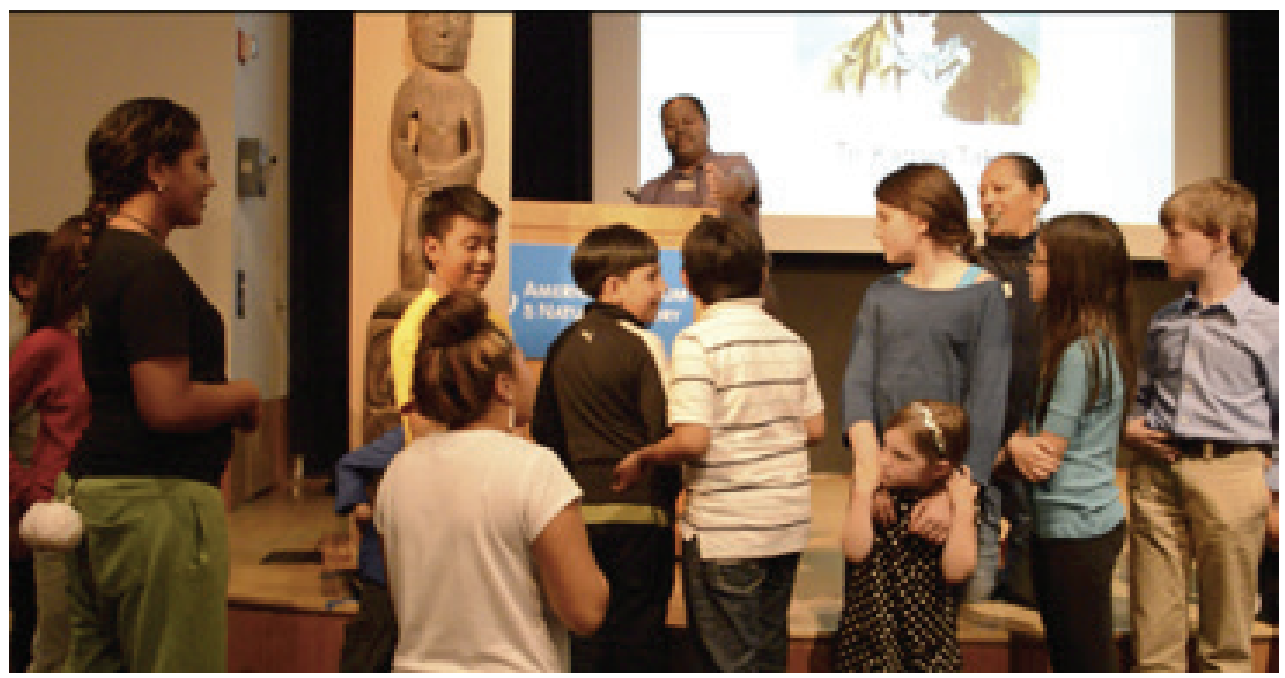

Fig. 11. Whakapapa with children: education session with Toi Hauiti. 18 April 2013. Photo: J. Newell

Reciting the whakapapa of Paikea in the house of stories in New York provided a network of significance for what had formerly been considered an 'object', turning it into something with personhood, a gendered, specific, active, historical figure with a biography of longue durée who is part of a complex web of relationships; a figure to whom visits should be made and gifts should be given to keep him company and keep him warm. Ngata started each session pointing to Paikea, next to him on stage, and saying 'I want to introduce you to this person...' 


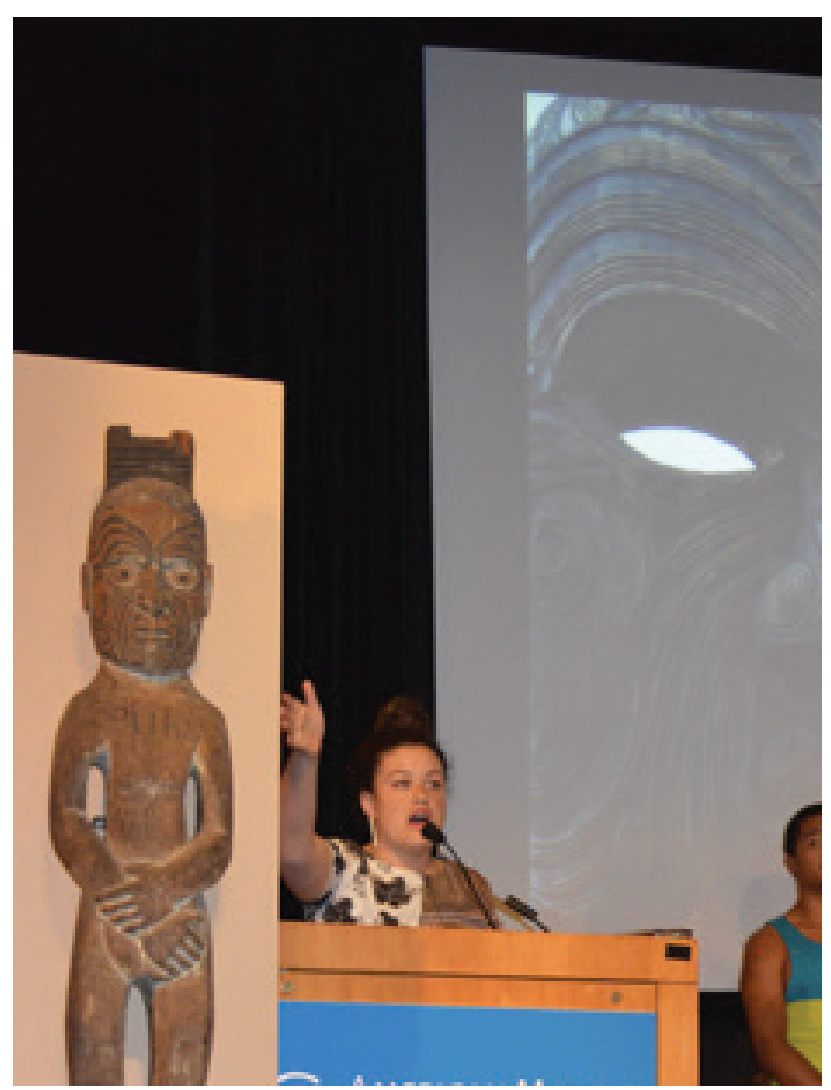

Fig. 12: Hine Te Ariki Parata-Walker introduces Paikea. 18 April 2013. Photo by J. Newell.

\section{Running adaptive sessions for different audiences}

Sessions were adapted according to age and other criteria, but each group received the same basic information: the story of Paikea that began this paper; his whakapapa, and its incorporation of every Toi Hauiti member; the importance of taonga to Toi Hauiti in particular and Māori in general; and an active lesson that required audience members to stand up and learn the first few lines of Paikea's haka and the actions that go with them.

The different ways the sessions were run were determined by Ngata's ability to quickly read his audience and adapt to suit. Though he calls this 'common sense', it is rooted in his years of experience as a schoolteacher, and his role as an advisor to the Ministry of Education in Aotearoa New Zealand. Likewise, the ability of his team to 'think on their feet' owed much to its make-up: many were school students; some are educators; all have strong links to Uawa's local school.

Aside from their commitment to education, Toi Hauiti are all involved in the day to day activities of their marae, the tribal communal meeting places where matters of significance are discussed, and meetings, birthdays, weddings and funerals are held. On the marae, people come together in self-organizing ways predicated on tikanga or appropriate and correct protocols. Whakapapa ties determine the roles each person plays in each event, and decisions about speakers, for example, are often not finalized until seconds before events begin. The Toi Hauiti members in New York were well schooled in this protocol, which is apparently spontaneous but is actually the result of having every member prepared to step in and lead any part of the presentations at $\mathrm{AMNH}$. For their part, AMNH staff were comfortable with this dynamic presentation style and enjoyed watching the changes made to each performance.

\section{Questions from the public}

Though the lectures given by Toi Hauiti were ostensibly object-centric, focused on Paikea in his instantiation as a wooden figure, the audience responses were not. 'What are your names?' one child asked; 'Do you have mobile phones in New Zealand?' ventured another. Where the latter caused much laughter among a group known for their early adoption of digital technologies (Ngata et al. 2012), the answer to the first question provided another opportunity to discuss whakapapa as each Toi Hauiti member explained their name and its whakapapa connections. Another child asked Ngata, 'Is that pen on your face?' Alison Waru stepped forward to answer, explaining that the moko is permanent and also records whakapapa. Waru described the process of getting her own moko kauae and the feeling she had when looking at herself in the 


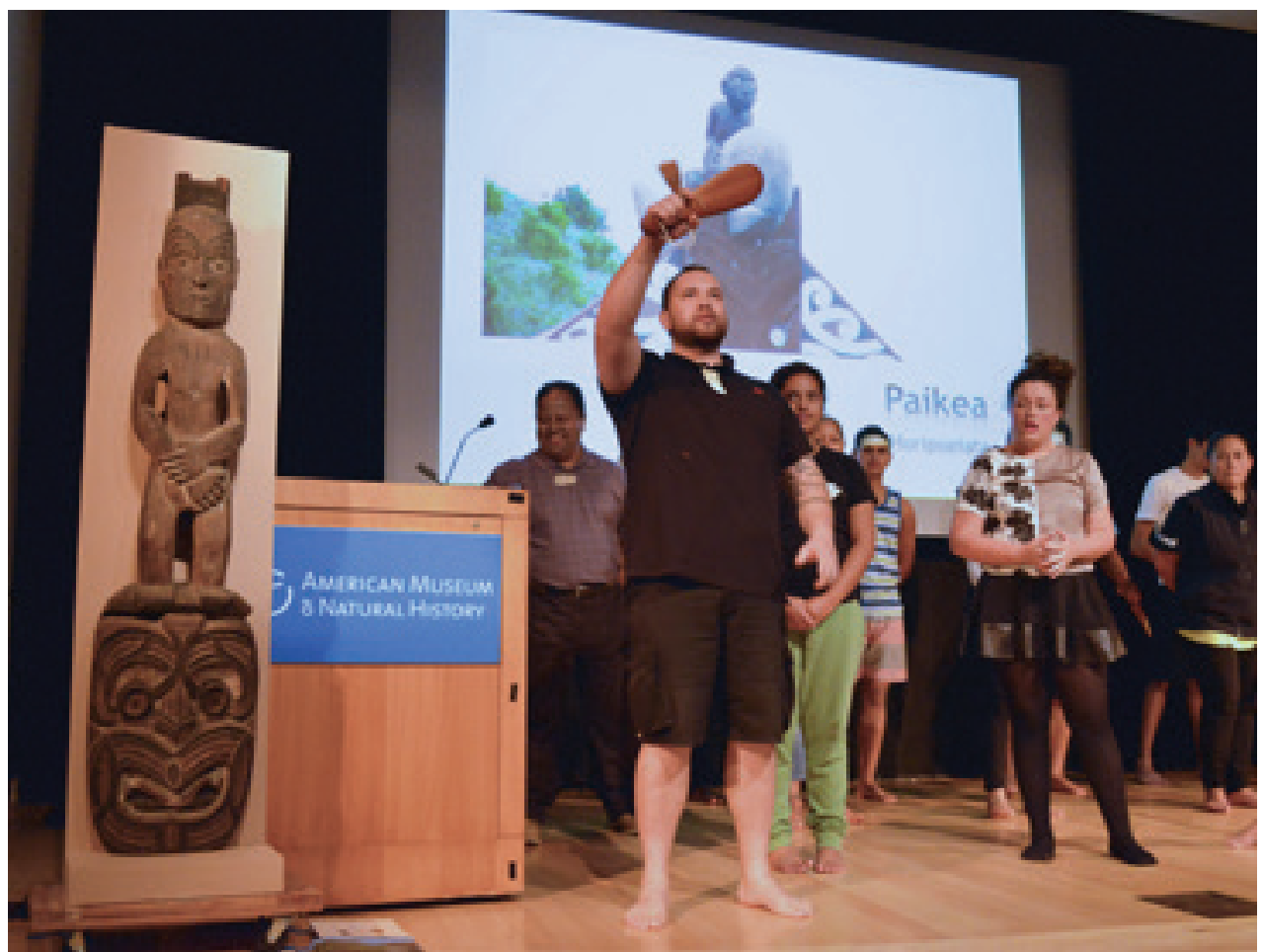

Fig. 13 Lance Ngata, Toi Hauiti carver, with a mere, addresses audience. 18 April 2013. Photo by J. Newell.

mirror for the first time afterwards: 'Oh, there you are', she said, 'It was as though I already knew that face'.

Though they might seem flippant, these were questions directed towards knowing more about the people on stage than about Paikea; fittingly, their answers served both purposes. The lectures blended the tangible and intangible and thus were both object-centric and people-oriented (Fouseki 2010: 186-8). The sessions with Paikea moved audiences beyond generalization - 'I saw a Māori carving' - to specificity and intimacy - 'I met Te Aotaihi from Uawa, Paikea is her ancestor. Te Aotaihi and her friends have cellphones like me. She is named after her ancestress, and her name means 'to be lifted on high".

\section{The power of the object cloaked in stories}

Stéphane Martin, président of the Musée du Quai Branly, has spoken of the preoccupation of Anglo Saxon and American curators with starting with the story (Naumann 2006). He sees this as a substantial contrast: 'European and French curators will always start with the object'. There is even a law, he says, 'describing what is a museum and its first article as a museum is a collection.' For us, we three writers from a variety of cultural, national and professional traditions, the object and its stories are intertwined. For Toi Hauiti, without its stories an object is simply that: an object.

As Fouseki reminds us, there are 'hidden histories', histories that curatorial staff are not informed about (Fouseki 2010: 182); stories about an object that a community has that are not yet - and perhaps never will be - relayed to curators. Toi Hauiti were willing to share the Paikea and Te Kani a Takirau story with museum staff and visitors; however, there is a limit to how much can meaningfully be shared. To ultimately engage in the story of Paikea is to immerse oneself in the places, language, knowledge systems and culture of Te Aitanga a 


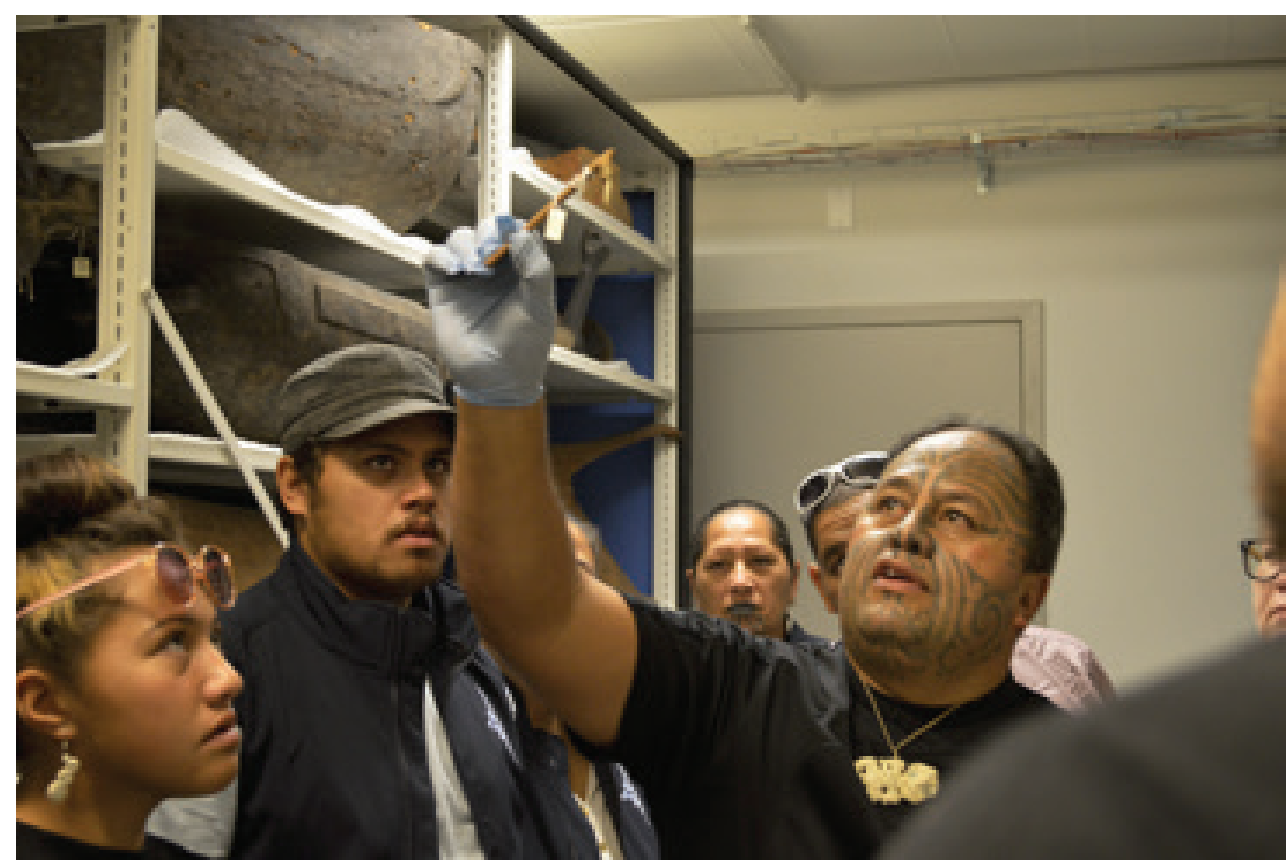

Fig. 14. Toi Hauiti in the AMNH storeroom: Wayne Ngata holds a tattoo chisel. 17 April 2013. Photo by J. Newell.

Hauiti. Paikea is a living embodiment of a Polynesian relationship with Tangaroa (god of the sea), with the houses of learning that taught and passed on the lore of Tangaroa, particularly the knowledge of carving. These are bodies of knowledge not entirely open to outsiders and more readily engaged with through the genealogy, language and customs of Paikea's descendants.

In time, as relationships between those inside and outside the museum become less distinct, we can imagine that meanings will be shared more fully, and culturally divergent houses of stories will be able to work in ever more productive collaboration.

\section{Storeroom education sessions}

Within the bodies of knowledge that could be shared in New York were stories and mātauranga relating to other things in the museum's stores. In some cases, pieces within anthropology collections are extremely well documented and provenanced, but more often the objects themselves have followed such complicated trajectories that there are scant or no records to work with. It was valuable for collections and curatorial staff to work closely with Toi Hauiti, whose oral traditions and ongoing production of objects furnished vital details about otherwise 'orphaned' objects. Likewise, it was valuable for Toi Hauiti to examine other things from Aotearoa-New Zealand, some made long ago and others made more recently, and discern how they contribute to mātauranga Hauiti. With so many carvers and artists in the group these sessions were particularly insightful; notes were made and photos were taken, both for use within the AMNH and for Toi Hauiti to take home.

\section{Conclusion}

This paper has examined how sharing narratives and consequent understandings can facilitate an engagement that allows sustained, deep and mutually-rewarding outcomes for its immediate participants and the audiences they reach out to. Our discussion has been anchored by the importance of taonga for Hauiti's descendants, and the ongoing outreach activities of both Toi Hauiti and the AMNH. At the heart of our discussion have been the embodied forms of 
knowledge used by Toi Hauiti to know Paikea in his absence, and the ways these were mobilized to introduce him to diverse audiences in New York and effect humanized experiences.

Toi Hauiti's time of in-reach at the Museum - their visiting Paikea - was also an effective outreach, through the public presentations they gave to introduce their ancestor to a broad audience. Their visit also provided an opportunity to integrate the two parallel stories about Paikea from both the Hauiti and the Museum's perspectives, piecing together Paikea's story more completely. By utilizing their own time-honoured methods to know Paikea, including haka, waiata ā-ringa and recitals of whakapapa, Toi Hauiti were able to effect compelling introductions to their audiences in New York, across diverse age groups and ethnicities. Their presentations also facilitated their sharing significant performative time with Paikea, during which their relationships with him, and inclusive of their ancestors and people at home in Uawa, were activated.

The week of Toi Hauiti's visit at the AMNH was a warm, emotional, and important shared experience, but it was also a constantly negotiated one. The successes and stresses of the engagement were determined by how much the Museum was prepared to relax their norms of control, how often Toi Hauiti gracefully did not comment on the things that dismayed them with regard to their taonga, and general good humour and flexibility from both. Among the issues quietly negotiated between AMNH staff and Toi Hauiti was the big question: Who owns this taonga, Paikea? Not just legally, but morally? Who should control his many facets: his physical form, his meanings, his limitless potential? Can that control be shared in a way that meets the needs of both the descendants and the institution, and more generally, how can AMNH represent the diversity that colonization, globalization and migration have brought to it? (Lagerkvist 2006: 52). While the goal of rebuilding the house initially in digital form will go some way towards reconfirming the relationships mentioned, ideally Toi Hauiti would like to take this Paikea tekoteko home to his people, his descendants who have not seen him but know him intimately.

Toi Hauiti's visit to Paikea and the subsequent process of writing this paper (not to mention the research of Bethany Matai Edmunds in 2009) have refocused attention on another Māori ancestral figure at AMNH: Hautuoterangi. At the time of writing it is not known if the figure is still extant, but there is renewed interest in seeing whether this warrior can be found and reacquainted - like Paikea - with his people.

Outreach, in-reach, object handling, facilitating reminiscence, are all parts of what Charterjee and colleagues have called 'the wider social care role' of museums (Chartejee et al. 2009: 165), which extends to the need to care for museum objects in ways sympathetic to the way they would be cared for at home. For now, Paikea is stored upright on his mount on the main floor of a storeroom that has visitors coming through it, rather than lying on a dark shelf in isolation. Social care must also be extended to source communities and the facilitation of their visits, including catering for unexpected events. After Toi Hauiti had left New York, Museum of New Zealand Te Papa Tongarewa's exhibition team came to deinstall the Whales exhibition. They visited Paikea and greeted him formally and warmly. During the week, one of the team members heard that he had lost a family member back in Aotearoa; he spent time grieving with Paikea, and other taonga in the storeroom from places he had ancestral connections with.

Efforts to decolonize museums (Wintle 2013), to forge relationships of shared authority over objects, and to educate museum audiences in multi-cultural contexts can be substantially advanced by bringing together not only present people but also ancestors. This means finding ways to include insights and the presence of the people currently surrounding an object, as descendants and as institutional caretakers, and overtly bringing in the long chains of people connected to the object through time, as Toi Hauiti did in their active, embodied, and photographic presentations to the public at the AMNH. The meaning for Toi Hauiti of the Paikea tekoteko as a person is a meaning that has existed, uninterrupted, in their community since the carving of the tekoteko in the 1880s. If the meaning of Paikea as a person can start to be understood and respected by the Museum, we have the foundation for an effective relationship. Likewise, if the understanding of Paikea as a person facilitates the understanding of Toi Hauiti as people, we will have achieved a foundation for stronger cross-cultural relationships.

Received:11 October 2014

Finally Accepted: 6 March 2015 


\section{Notes}

1 Aotearoa, 'land of the long white cloud', is the Māori name for what is now more commonly called New Zealand. Aotearoa-New Zealand is a naming convention that reflects the bicultural relationship of Tangata Whenua ('people of the land': indigenous Māori) and Tangata Tiriti ('people of the Treaty of Waitangi': non-Māori). Importantly for this paper's central concerns, this bicultural nomenclature and greater relationship is reflected in the governing structure of the national musuem, The Museum of New Zealand Te Papa Tongarewa, and resources developed therein for other museums and institutions to utilize.

http://www.tepapa.govt.nz/NationalServices/Resources/FundingPlanningManagement/ Pages/Biculturaldevelopment.aspx

2 Whale Rider Film education pdf, http://www.filmeducation.org/pdf/film/WhaleRider.pdf, p.4. Accessed 9 March 2014.

3 Originally titled Whales Tohorā. The exhibition ran at the AMNH from March 2013 to January 2014.

4 http://collections.tepapa.govt.nz/exhibitions/whales/Accessed 12 March 2014

5 Augustus Hamilton (1854-1913), botanist, zoologist, ethnographer and collector. He was first a school teacher in Hawkes Bay, later Director of Wellington's Dominion Museum. A. H. McLintock (ed.), An Encyclopedia of New Zealand (1966).

$6 \quad$ William John Phillipps (1893-1967) studied and published on Māori 'life and customs' and Māori carving (from 1941 to 1966). He also published in ichthyology. His report reflects the difficulty in tracing histories of meeting houses during this era; there are three houses (at least) that he has apparently mixed the images and identifications of. Phillipps reproduces the photograph of the house with the Paikea tekoteko (our fig. 2, above) as Plate 45, fig. 2 and describes it as one of four houses in Tolaga Bay, naming it 'Tolaga Bay House (2)' (pp. 105-106). Phillipps goes on to describe 'Tolaga Bay House (4)' as Te Kani a Takirau, describing its history (pp. 107-108), illustrating it in Plate 46, fig. 2. However, the house in this plate and in his written description is actually the house now in the Field Museum, Chicago, Ruatepupuke 2. Phillipps describes 'Ruatepupuke 2' on p. 110, covering its history and the sale of the house to the Field Museum, but there is no photograph. In other words, Phillipps' Report should not be taken as the final word on identification.

7 The accession file for this purchase includes a copy of J.C Steven's auction catalogue, 29 and 30 October, 1907 (AMNH Anthropology archive, accession file 1908-8). Only some of these items are clearly listed. Lot 170: 'New Zealand carved plank, two tattooed figures in high relief...taken from the wall of the Rununga whare' is followed by an ambiguous description of Lot 171: 'Ditto, somewhat similar'. While this could potentially be construed as a reference to the Paikea tekoteko, it is a stretch. It is more likely that the tekoteko came through a different auction house: in the 1908 photo the tekoteko has an auction house number, 'Lot 110' on its leg.

8 'The Mighty Maoris' by Bethany Matai Edmunds. http://blogs.nyu.edu/blogs/hg26/ amnhphotographs/2009/04/the mighty maoris.html\#more Accessed 9 March 2014.

9 Ibid.

10 http://www.amnh.org/our-research/anthropology/collections/database Accessed 9 March 2014. 
11 Full entry reads: Catalog No: 80.0/ 615; Culture: MAORI; Locale: NORTH ISLAND, TOLAGA BAY (TOLOGO BAY); Region: POLYNESIA; Country: NEW ZEALAND; Date: Late $19^{\text {th }}$ Century A.D.; Material: WOOD, PIGMENT; Dimensions: L:164 W:42 H:19 [in CM]; Acquisition Year: 1908 [PURCHASE]; Donor: ROBLEY, MAJOR GENERAL

12 http://maa.cam.ac.uk/aofe/news florence 09 2012.html, accessed 10 September 2014

13 Project website: http://maa.cam.ac.uk/aofe/, accessed 14 March 2014.

14 http://maa.cam.ac.uk/aofe/news vancouver workshop 04 2013.html, accessed 10 September 2014.

15 http://maa.cam.ac.uk/aofe/news disco workshop 2010.html, accessed 10 September 2014. Proceedings published as Lythberg, B. and A. Salmond (eds.). Digital Subjects, Cultural Objects. Special Edition of Journal of Material Culture 17:3 (September 2012).

16 Hine Te Ariki Parata-Walker, April 2013.

17 Native American Graves Protection and Repatriation Act (1990).

\section{Acknowledgements}

Thank you to two anonymous reviewers whose comments strengthened our paper, and to the editors for their tireless support.

Toi Hauiti were represented in New York by Taylor-Paige Aroha Paaka-Selwyn; Te Ata Po Kirikiri; Manuel Wehi; Owen Wharekaponga Rayner; Whetu Kerehona Rangihaeta; Hinemaia Evelyn Matehaere Kupenga-Keefe; Te Aotaihi Kutia-Ngata; Kelly Hariata Keelan Blackman; Lance Ngata; Te Rauhuia Ngata Kutia; Rawinia Jane Kutia; James Wayne Ngata; Hine Te Ariki Parata-Walker; Alison Michele Anne Waru; Hataraka Gibson.

AMNH participants included Paul Beelitz, Anita Caltabiano, Bella Desai, Jacklyn Lacey, Judith Levinson, Dean Markosian, Karl Matsuda, Laurel Kendall, Monique Scott, Joel Sweimler, Adina Williams.

Billie Lythberg traveled to New York with the support of a Collection Study Grant from American Museum of Natural History and Richard Gilder Graduate School, New York, and Cambridge University Museum of Archaeology and Anthropology's Economic and Social Research Council funded project 'Artefacts of Encounter'.

\section{References:}

Brown, D., (2008), 'Ko te Ringaringa ki nga Rakau a te Pakeha': Virtual Taonga Māori and museums', Visual Resources 24(1) 59-75.

Brown, D. and G. Nicholas, (2012), 'Protecting indigenous cultural property in the age of digital democracy: Institutional and communal responses to Canadian First Nations and Māori heritage concerns', Journal of Material Culture, 17(3) 307-324.

Candlin, F., (2007), 'Hands Off! Don't Touch! Art, Blindness and the Conservation of Expertise', in E. Pye (ed), The Power of Touch: Handling Objects in Museum and Heritage Contexts, 89-106, Walnut Creek: Left Coast Publishing.

Chatterjee, H., Vreeland, S. and Noble, G, (2009), 'Museopathy: Exploring the Healing Potential of Handling Museum Objects', Museum and Society, 7(3) 164-177

Clarkin-Phillips, J., Paki, V., Fruean, L., Armstrong, G. and Crowe, N., (2012), 'Exploring te ao Māori: the role of museums', Early Childhood Folio, 16(1) 10-14. 
Classen, C., (2007), 'Museum Manners: The Sensory Life of the Early Museum', The Journal of Social History, 4(4) 395-914.

Clifford, J., (1997), Routes: Travel and Translation in the Late Twentieth Century, Cambridge, MA: Harvard University Press.

Connerton, P., (1989), How Societies Remember, Cambridge: Cambridge University Press.

Edmunds, B. M., (2009), 'The Mighty Maoris', NYU Museum Studies Blog, http://blogs.nyu. edu/blogs/hg26/amnhphotographs/2009/04/the mighty maoris.html\#more

Edwards, E. and Mead, M., (2013), 'Absent Histories and Absent Images: Photographs, Museums and the Colonial Past', Museum and Society, 11(1) 19-38.

Fouseki, K., (2010), 'Community voices, curatorial choices: community consultation for the 1807 exhibitions', Museum and Society, 8(3) 180-192.

Kotler, N. and Kotler, P., (2000), 'Can Museums be All Things to All People?: Missions, Goals, and Marketing's Role', Museum Management and Curatorship, 8(3) 271-287.

Lagerkvist, C., (2006), 'Empowerment and Anger: learning how to share ownership of the museum', Museum and Society, 4(2) 52-68.

Lythberg, B., (2013), 'Anthropology Collections Database, a website of The American Museum of Natural History (review)', Journal of Museum Ethnography, 26 181-186.

Lythberg, B. and Salmond, A., (eds), (2012) Digital Subjects, Cultural Objects, Special Edition of Journal of Material Culture 17 (3).

Lythberg, B., Hogsden, C. and Ngata, W., (Forthcoming 2015) "'Relational Systems": Cocreating a Digital Contact Network in Theory and Practice', in S. Hawke, B. Onciul and M. Stefano (eds), Engaging Communities, Suffolk: Boydell and Brewer.

Naumann, P., (2006), 'Making a Museum: "it is making theater, not writing theory": An Interview with Stéphane Martin, Président-directeur général, Musée du quai Branly', Museum Anthropology 29(2) 118-127.

Neich, R., (2003), 'The Maori house down in the garden: a benign colonialist response to Maori art and the Maori counter response', The Journal of the Polynesian Society, 4, 331-368.

Ngata, W., Ngata-Gibson, H. and Salmond, A., (2012), 'Te Ataakura: Digital taonga and cultural innovation', Journal of Material Culture, 17 (3) 229-244.

Peers, L., (2013), '“Ceremonies of Renewal”: Visits, Relationships, and Healing in the Museum Space', Museum Worlds: Advances in Research 1, 136-152.

Phillipps, W. J., (1944), 'Carved Maori Houses in the Eastern Districts of the North Island', Records of the Dominion Museum, 1 (2) 69-119.

Porter, G., (1989), 'The Economy of Truth: Photography in the museum', Ten-8, 34, 20-33.

Robley, H., (1896), Moko; or Maori Tattooing, London: Chapman and Hall Ltd.

Schorch, P., (2013), 'Contact zones, Third Spaces, and the Act of Interpretation', Museum and Society, 11(1) 68-81.

Simpson, A. and Hammond, G., (2012), 'University collections and object-based pedagogies', University Museums and Collections Journal, 5, 75-82. 
Wagelie, Jennifer, (2007), Maori Art in America The Display and Collection History of Maori Art in the United States 1802-2006, Unpublished PhD Dissertation, The City University of New York.

Wintle, C., (2013), 'Decolonising the Museum: The Case of the Imperial and Commonwealth Institutes', Museum and Society, 11(2) 185-201.

\author{
Authors \\ Dr Billie Lythberg \\ Research Fellow \\ Mira Szászy Research Centre, \\ The University of Auckland Business School \\ Owen G Glenn Building, \\ 12 Grafton Road, \\ Private Bag 90219, \\ Auckland 1142, \\ New Zealand \\ b.lythberg@auckland.ac.nz
}

*Billie Lythberg is a Research Fellow at the University of Auckland Business School where her interests are indigenous economies and aesthetics, with particular foci on Māori and Tongan arts and literatures and the contexts in which these emerge and are valued and exchanged. Previously a research associate for 'Artefacts of Encounter' at Cambridge University Museum of Archaeology and Anthropology (MAA), Billie continues to work with artefacts (both tangible and intangible) of eighteenth-century encounters between Polynesians and Europeans, exploring their legacies and relevance today. She is currently co-editing volumes on the eighteenth-century collections of MAA, French navigator Bruni d'Entrecasteaux, and Spanish explorer Malaspina. Museum's Pacific collection.
Dr Jennifer Newell
Curator Pacific Ethnography
Anthropology Division, American Museum of Natural History
Central Park W \& 79th St,
New York, NY 10024,
United States
inewell@amnh.org

** Jennifer Newell is curator of Pacific Ethnography at the American Museum of Natural History, New York. Her particular interests are in material culture and the relationship between Pacific Islanders and their environments. Dr. Newell previously worked in the Oceanic section at the British Museum (2001-2008) and the National Museum of Australia (2008-2012). She has worked closely with Pacific diaspora communities, and with individual curators, artists and scholars in the Pacific. Her first book, Trading Nature, explored the environmental and cultural implications of exchanges between Tahitians and Europeans in the eighteenth and nineteenth centuries. Her second, Pacific Art in Detail, contextualised key objects in the British

***Wayne Ngata is currently working as a director of research at Te Taura Whiri i te Reo Māori (Māori Language Commission). He is also a Principal Investigator with $\mathrm{Ngā} \mathrm{Pae} \mathrm{o} \mathrm{te}$ Māramatanga, the Centre for Research Excellence focused on indigenous research, based at the University of Auckland where he is helping develop digital solutions for indigenous people to connect with their cultural artefacts. As well, he is helping develop models of tribal development as a research fellow with Te Whare Wānanga o Awanuiārangi, Whakatāne; and 
is a member of Te Mata o Te Tau, the Academy for Māori Research and Scholarship at Massey University. His area of scholarship is Māori literature, specifically the language of mōteatea (traditional chant). He has worked extensively over the years to support the revitalisation of te reo Māori in schools and communities through his various roles with; the Ministry of Education, Te Taura Whiri i te Reo Māori, and the Eastern Institute of Technology, and more importantly as a member of a growing group of Māori language activists across Aotearoa-New Zealand. $\mathrm{He}$ is an active advocate for Māori tribal intellectual, social and economic development.

\author{
Dr Wayne Ngata \\ Director Research Maori Language Commission \\ 34 Monkhouse Street, \\ Tolaga Bay 4077, \\ New Zealand \\ wjn@xtra.co.nz
}

